\title{
The Diversification of Production
}

MOST FIRMS TODAY produce more than one product. In this sense their production is diversified, or horizontally integrated. This paper addresses two questions. First, why have firms become more diversified over the past century? And second, why are diversified firms more oriented toward research and development (R\&D) than nondiversified firms?

I tackle these two questions under the assumption that a firm diversifies to maximize its efficiency. Economists have often argued that a firm reaps efficiency gains when it diversifies its production because its managerial and R\&D inputs can be shared among its various activities:

The sphere in which diversification is most likely to produce economies of scale is research and develoment. Although the information thus far gathered on this question is inconclusive, it is reasonable to say that a firm with a wide range of products has many opportunities for exploiting the results of a program of research. This is because the directions in which research will produce results are to a large extent unpredictable. Consequently, the greater the range of activities, the higher are the chances that a discovery or development in technology will fit into the firms' existing product structure. In this sense, economies are related not so much to size in terms of output or investment as to the range of goods

I thank the C. V. Starr Center for Applied Economics at New York University for technical and financial help; Martin Baily, Michael Gort, Yaw Nyarko, Steve Olley, Peter Reiss, Mike Scherer, Clifford Winston, and the discussants for useful comments, and Ray Atje and Chung Yi Tse for help with the research. Two earlier versions of this work were presented in an economic fluctuations group organized by Ricardo Caballero and Andy Caplin, and this exercise led to considerable improvement. 
and services produced. If the level of research and development expenditures continues to rise rapidly, we can expect an increase in diversification motivated by these considerations. ${ }^{1}$

The idea that know-how can be productively transferred from one activity to another has also been pursued by growth theorists, some of whom argue that spillovers of knowledge among distinct production processes are the engine of growth. ${ }^{2}$ Nor is R\&D the only input that can be shared among the firm's products. Managerial know-how, as well as other indivisible factors, can be used to make, promote, and distribute more than one product at a time.

I shall embed these much-talked-about but still relatively unexplored ideas in two multiproduct versions of Lucas's span-of-control model, which is a general equilibrium model of firm formation. ${ }^{3}$ Because the trend toward diversification is visible in most sectors despite the technological differences among them, one suspects that these sectors share a reason for this trend, a force that operates at the economy-wide level. The first version of the model isolates the role of the shared managerial input in explaining the trend. The second focuses on the positive relation between diversification and R\&D. In both models firms are infinitesimal, they set price of output at marginal cost, and diversification is socially optimal. In fact, firms often have market power, and antitrust policy must then trade off efficiency gains to diversification against its anticompetitive effects. The Justice Department's merger guidelines recognize the possibility that most mergers are not anticompetitive and that they can raise efficiency and benefit the consumer. ${ }^{4}$

The paper has two main conclusions. First, the secular increase in the capital-labor ratio is a major cause not only of the growth of firm size, but probably also of increased diversification. Second, cross-product spillovers in R\&D within the firm seem to be significant. I estimate that a diversified firm gets between 1.025 and 1.3 times as much from

1. The passage is from Gort (1966, p. 35). Penrose (1959) may have been the first to argue that firms diversify to take advantage of slack managerial resources and possibly slack technological resources such as R\&D. See also Richard Nelson (1959). Panzar and Willig (1981) prove that the presence of what they call economies of scope is equivalent to the presence of a shared input.

2. Stokey (1988); Young (1991); and Lucas (forthcoming).

3. Lucas (1978).

4. U.S. Department of Justice (1992, p. 30). 
its $R \& D$ as a single-product firm would. The estimate is rough and subject to all sorts of qualifications.

The model aims to fit evidence that I shall survey below. Some of that evidence, however, is consistent with other motives that have been held to drive firms to diversify, motives other than efficiency. To put my model in perspective, then, the next section briefly surveys some reasons why firms diversify.

\section{Why Diversify Production?}

When analyzing the vertical integration of two firms, the alternative is usually taken to be a potential buyer-seller relationship between them, in which case bilateral monopoly, if it is not there initially, can develop over time between them as they make specific investments in their relationship. ${ }^{5}$ Vertical integration can thus be seen as the firms' attempt to wipe out efficiency losses that bilateral monopoly generates. No such motive exists with horizontal integration, and although some of the motives discussed below can also be construed as driving vertical integration, horizontal integration is qualitatively different. Here are some possible motives for it.

Gaining Market Power. A firm with market power in two substitute products can extract more from the consumer than would two singleproduct monopolies acting noncooperatively, and this may hurt welfare. Since most diversified firms have negligible shares of the markets they serve, however, other motives must be examined. ${ }^{6}$

Avoiding Risk. Without bankruptcy risk and liquidity constraints, the firm need not diversify to avoid risk - the shareholder can do it himself. ${ }^{7}$ But with incomplete insurance possibilities, this motive may be important, especially for smaller firms whose investment seems to depend

5. A point emphasized by Williamson (1979).

6. Utton (1981, chap. 7) and Willig (1991) discuss possible anticompetitive effects of horizontal mergers. Ralph Nelson (1959) argues that the quest for market control fueled the first big merger wave in the United States in 1898-1902. Ravenscraft and Scherer (1987), however, dismiss this motive for all but a few of the later mergers they studied.

7. Levy and Sarnat (1970, section 1). A natural way to analyze this motive is to add multigood production to Kihlstrom and Laffont's (1979) model. 
more on cash flow. ${ }^{8}$ Note that the risk avoidance motive cannot explain vertical integration, because vertical integration in effect makes a firm put more of its (investment) eggs in the same (final market) basket.

Having Access to Funds. When capital markets are imperfect, an investment opportunity might go not to the most efficient producer but rather to the producer who has the funds to finance it. Noticing an opportunity in another industry, a firm with enough funds may diversify into it even if multigood production is costlier than specialization. This hypothesis should apply especially to large firms, which can raise capital more easily and quickly than can small firms, ${ }^{9}$ and to industries where setup costs are high. It gets support from the finding that a diversifying firm typically enters industries that are commonly populated by large firms and that the diversifying entrant is typically bigger than the startup firm. ${ }^{10}$

Making Products Compatible. If products are supplied by different firms, a socially suboptimal array of product types could emerge. A firm could raise its profits, and possibly consumers' welfare too, if it produced the optimal product set jointly. It could do so, that is, even if producing the products together entailed no underlying cost advantage. This may be an important motive in areas such as consumer electronics and computers. It differs from a "network externality," in which the volume of sales of a product, such as a telephone, gives rise not to economies of scope, but to economies of scale emanating from the demand side of the market. This motive can also cause a firm to integrate vertically to ensure that it will have the right combination of inputs and thereby raise the value of the chain of production.

Reaping Efficiency Gains. By making several products, a firm may increase its sales and may realize economies of scale in promoting, advertising, and distributing its products. The diversified firm may also need workers to perform a greater variety of tasks and will therefore offer them a richer internal labor market. ${ }^{11}$ These are productive advantages of diversification. ${ }^{12}$

8. Fazzari, Hubbard, and Petersen (1988).

9. Scherer and others (1975, pp. 284-9).

10. Stigler (1962) makes the first point, MacDonald (1985, table 1, p. 587) gives evidence that supports it, and McCutcheon (1990) gives mixed evidence. Baldwin and Gorecki (1987) make the second point.

11. Prescott and Visscher (1980) treat a related issue from this perspective.

12. Baumol, Panzar, and Willig (1982) call them economies of scope. 
Pursuing Managerial Goals. A manager may do things that do not maximize the firm's profits or its shareholders' welfare. Even if the firm is not cash-constrained, the manager may diversify to reduce the uninsurable employment risk. ${ }^{13}$ Because managerial power and prestige seem to be tied more closely to the firm's sales than to its profits, the manager may pursue conglomerate mergers - a quick way to raise the firm's sales. ${ }^{14}$ In addition, because a diversified company often aggregates information from several lines of its business into one consolidated financial statement, managers may prefer to diversify to reduce the accuracy with which their activities can be monitored. ${ }^{15}$

\section{Evidence}

Among the many motives for diversification listed above, I single out the pursuit of efficiency gains and see how far it can be pushed as an explanation of the facts on diversification. The two major stylized facts that emerge from the many empirical studies are a trend toward diversification and a greater R\&D intensity within diversified firms. To strengthen the motivation for the type of model that I will use, I summarize the relevant evidence.

To measure diversification, an industrial classification is first chosen to determine which of the firm's products are distinct. One measure then simply counts the kinds of products the firm makes, but because this method ignores the relative importance of products, the firm's sales are usually used as weights. A popular example is the Herfindahl index: $D=1-\sum_{i=1}^{n} p_{i}^{2}$, where $p_{i}$ is the ratio of the firm's sales in the $i^{t h}$ industry to its sales in all $n$ industries. This measure does not pick up any vertical integration because if a firm supplies itself with an input, it gets no revenue from the activity per se. The empirical results largely do not depend on the choice of index. ${ }^{16}$

13. Amihud and Lev (1981) give evidence in favor of this proposition.

14. Mueller (1969) develops this view and cites evidence favoring it.

15. Lichtenberg (1991).

16. Gollop and Monahan (1991) discuss several indexes. 
Next, one can measure the diversification of firms or their plants. Most of the work deals with firms. ${ }^{17}$ It turns out that industries that have more diversified firms also tend to have more diversified plants. ${ }^{18}$ Most samples are cross-sections or short panels. ${ }^{19}$ Let us begin with the time-series results.

\section{The Trend Toward Bigness and Diversification}

Over the past century, business has grown bigger and more diversified. ${ }^{20}$ Gort's work, after thirty years still the definitive work on the subject, shows a clear increase in diversification between 1929 and 1954 , when he uses a measure that emphasizes the number of products. Another sensible measure of diversification is the share of sales coming from the firm's primary activities, in Gort's case the four-digit industry from which the firm derives most of its sales. In his sample of 111 large manufacturing companies, the ratio of primary industry payrolls to total company payrolls declined only slightly, from 69 percent in 1929 to 64 percent in $1954 .{ }^{21}$ By this measure, then, diversification went up hardly at all. Still, other measures show a marked increase until quite recently. The first big wave of mergers in the United States was in 1898-1902, an episode that must have raised both the size and diversification of firms. ${ }^{22}$ And in a sample of 471 large U.S. manufacturing firms, the number of four-digit manufacturing categories in which the companies operated rose from 2.55 in 1950 to 7.54 in $1975-\mathrm{a}$ threefold increase. ${ }^{23}$ Firms in other countries also became more diversified. Utton's sample of large firms in the United Kingdom shows an increase until the 1970s. A sample of large Japanese firms shows an

17. There are exceptions: Streitweiser (1991) looks at five-digit diversification of plants, while Gollop and Monahan (1991) look at both manufacturing firms and plants at the twodigit level.

18. See Gollop and Monahan (1991, tables 1 and 2, p. 326) For instance, the crosscountry correlation coefficient between plant diversification and firm diversification for 1963 was 0.76 .

19. Gort (1962) is the major exception; his panel covers twenty-five years.

20. Berle and Means (1968, pp. 354-8); Prais (1976, chart 6.1); Scherer (1980, figure 3.1); Strickland (1984, table 3, p. 6); and figure 2 herein.

21. Gort (1962, chap. 3).

22. Ralph Nelson (1959, p. 3, chart 1).

23. Ravenscraft and Scherer (1987, table 2-3). 
increase in diversification from 1963 to 1975 , as well as some procyclicality, as does Nelson's sample on mergers. ${ }^{24}$

So much of firm growth occurs by merger and acquisition that it is no surprise that size and diversification move together. In a sample of 460 large U.S. corporations covering the 1960-65 period, Berry shows that the more diversified firms (especially at the four-digit rather than two-digit level) also grew significantly faster. The time-series correlation between size and diversification is thus apparent in Berry's sixyear panel, too. Jacquemin and Berry repeat the exercise on the same sample using a different measure of diversification-entropy rather than Herfindahl - and get even stronger results. ${ }^{25}$

Recently, firm size and diversification have both declined. The 1980s saw a fall in diversification through corporate spin-offs and asset sales. Gollop and Monahan's indexes show that after 1977 diversification fell both at the firm and at the plant level. ${ }^{26}$ On the decline of firm size, Prais's English data show no increase after 1963 in the share of the hundred largest firms in manufacturing value added ${ }^{27}$ Evidence for the United States, depicted in the figure below on firm size, shows that firm size has declined since 1980, which coincides with the period when diversification declined. Quite aside from the reversal in the growth of employment in the average firm, employment of the Fortune 500 firms has declined even more rapidly. ${ }^{28}$ Taken together, the time-series evidence shows that firm size and diversification have moved together; this is more than a mere manifestation of a common upward trend, because recently both have declined.

\section{Diversifying to Avoid Risk}

Risk avoidance does not seem to motivate diversification in that firms do not tend to choose stable industries when diversifying. ${ }^{29}$ Instead, they tend to diversify into technologically related industries, thereby exposing themselves to common technological shocks and hence more

24. Utton (1981, pp. 88-9); Goto (1981, fig. 1); and Ralph Nelson (1959, chap. 5).

25. Berry (1975, p. 67, table 4-5); and Jacquemin and Berry (1979, tables 4 and 5).

26. Gollop and Monahan (1991, tables 1 and 2, p. 326); and Lichtenberg (1990).

27. Prais (1976, table E.1). See also Scherer (1980, fig. 3.1).

28. The Wall Street Journal (1992) reports that their share of employment fell from 21 percent in 1969 to 10.9 percent in 1991 .

29. Gort (1962, pp. 4, 116-7). 
risk. ${ }^{30}$ Moreover, if big firms really find it easier than small firms to bear risk, it is surprising that they (and presumably more diversified firms as well) are no more likely than small firms to enter durable goods manufacture-cyclically the most volatile segment of manufacturing. ${ }^{31}$

Of course, in choosing a "portfolio" of industries, a firm would consider the industry's covariance with aggregate consumption. Perhaps countercyclical industries were indeed targeted, but this has not been investigated. A better way to think of diversification is as a form of exit and entry: firms diversify out of low-growth and into high-growth industries. ${ }^{32}$ Diversified entry and exit simply mean that a firm is not born when it enters an industry, and it does not die when it leaves.

\section{Cross-Sectional Evidence on Diversification and Size}

Big firms are more diversified than small firms. In 1954 Gort's 721 firm sample showed a strong positive association between the size of the firm and the number of industries in which it maintained establishments. ${ }^{33}$ That this should be true in the economy at large is hardly surprising since the conglomerates on the Fortune 500 list account for a big fraction of the nation's output. But it is also true at the industry level. Big pharmaceutical firms are more diversified than small pharmaceutical firms, big chemicals producers are more diversified than small chemicals producers, and big oil producers are more diversified than small oil producers. ${ }^{34}$

In his 721-firm sample, Gort found something that is at odds with other cross-sectional findings showing a link between diversification and size: the elasticity of primary employment to the firm's total employment is essentially unity. ${ }^{35}$ Because the number of secondary products increases with firm size in the cross section, the relative importance of a given secondary activity declines with the size of the firm. This cross-sectional result parallels Gort's time-series finding that the share of primary activities did not change much between 1929 and 1954. In

30. Hughes (1988); Hall (1988); Klavans (1989); and Chang (1992).

31. Gertler and Gilchrist (1992).

32. Gort (1962, p. 136); and Chandler (1977, p. 473).

33. Gort (1962, chap. 4).

34. Grabowski (1968, table 3); and Teece (1980, table 1). More evidence on the correlation between sales and diversification is in Scherer (1965, p. 115).

35. Gort (1962, p. 71). 
other words, the importance of a firm's primary activities is roughly constant in the cross section and in the time series.

\section{The Positive Relation Between Diversification and $R \& D$}

Gort's early work showed that more diversified firms employ relatively more technical personnel. This need not mean their ratios of R\&D to sales are higher, but it does suggest that they use a more complex technology.

Two other measures of a firm's inventive activity are its patents and its R\&D-sales ratio. Diversified firms patent more than other firms, but the effect is small: in a sample of 443 companies, Scherer found that the elasticity of patents with respect to his measure of diversification is $0.1{ }^{36}$ Firms' $\mathrm{R} \& \mathrm{D}$-sales ratios in most industries are positively related to how diversified the firms are. Even after controlling for scale, Grabowski found this positive relation in the chemical and drug industries but not in the oil industry. Working with a narrower measure of diversification, however, Teece did find a strong positive relation in the oil industry, after controlling for cash flow, which should serve as a proxy for firm size. ${ }^{37}$

That firms tend to move into products whose technologies are related to the technology of their primary product is further evidence for believing that diversification is related to (or perhaps represents) the capture of technological spillovers. High R\&D firms also tend to enter other high R\&D industries. ${ }^{38}$

Much research and development goes on in laboratories that are removed from production facilities, such as AT\&T's Bell Laboratories, a fact that suggests that spillovers of knowledge among parallel R\&D activities are not confined to the plant but occur largely at the firm level. Indeed, R\&D-sales ratios relate more strongly to the diversification of firms than to the diversification of their plants. Using eighteen two-digit manufacturing industries (so that there were eighteen observations in all), I found that the correlation between Gollop and Monahan's 1963 firm diversification index and the 1963 R\&D-sales ratio

36. Scherer (1983).

37. Grabowski (1968, table 1); and Teece (1980, appendix).

38. MacDonald (1985); and Hall (1988). Gort (1969) finds that firms with high technical personnel ratios had a greater tendency to merge. 
was 0.43 . The correlation between their establishment diversification index for the same year and the R\&D-sales ratio was 0.21 . The discrepancy between the correlations is present in other years as well. In 1977 , for example, the correlations were 0.23 and 0.03 , respectively. All this suggests that the capture of $R \& D$ spillovers should be reflected more in diversification of firms than of their plants. ${ }^{39}$

But not all evidence points to the capture of $R \& D$ spillovers as a motive for diversifying. First, the strength of the R\&D-diversification relation may be overstated because of the underreporting of $R \& D$ by smaller, less diversified firms. Many of these report no R\&D spending at all, yet they apply for patents and therefore must be making inventions. Second, the positive correlation between R\&D and diversification may be partly a spurious outcome caused by capital shortages, not R\&D spillovers. That is, it could be that big firms have the capital needed for entry into new product markets and for doing R\&D on a large scale. ${ }^{40}$ Third, Hall found that, if anything, mergers and acquisitions reduced the R\&D done by the companies in her short panel. The reduction in R\&D intensity was large-half a percentage point. She speculated that the increases in debt that accompanied the acquisitions made it harder for these firms to fund $R \& D .{ }^{41}$ (But one could also rationalize her result by arguing that following a merger, the firm may want to economize on a shared input such as $R \& D$, because a given amount of $R \& D$ can " 'go further."') Fourth, a study of pharmaceutical firms found that those with higher R\&D-sales ratios subsequently diversified less than other firms. ${ }^{42}$ Finally, if R\&D spillovers exist, they are an efficiency gain. And yet much of the acquisition-led diversification in the 1960s has been unprofitable for the acquiring firms. ${ }^{43}$ The divestitures of the 1980 s can then be seen as undoing previous mistakes, and this de-

39. Many studies (too many to survey here) have looked for-and most have foundevidence of economies of scope in specific areas such as advertising (Silk and Berndt, 1990), telecommunications (Evans and Heckman 1984; Kiss and Lefebvre 1987; Elixmann 1989), banking and financial institutions (Matthews 1981; Kim 1986; Hunter and Timme 1986), and water utilities (Kim 1987).

40. Himmelberg and Petersen (1991) find that after controlling for measures of Tobin's $q, \mathrm{R} \& \mathrm{D}$ spending by small firms is still sensitive to cash flow.

41. Hall (1990, p. 122).

42. Hill and Hansen (1991, table 2).

43. Morck, Shleifer, and Vishny (1990, table 4). 
diversification seems to have raised the productivity of the firms involved. ${ }^{44}$

All in all, however, the evidence shows a positive relation between $R \& D$ intensity and diversification. In linking $R \& D$ and diversification theoretically, two assumptions are key. First, distinct products often share the same technology - knowledge useful for producing one product can help with producing others too. Second, such spillovers of knowledge occur more freely within firms than among them. The first assumption agrees with casual observation. Moreover, evidence shows that a firm's cost curve is lowered by R\&D done by its technological neighbors, by the suppliers of its capital goods, or by firms in other industries more generally. ${ }^{45}$ Specific technologies that firms develop often originate with firms in other industries. ${ }^{46}$ The second assumption follows if the firm enjoys a lead time in having the sole use of its own inventions. The length of this lead time probably depends on such factors as the ease of patenting, the size of the firm, the industry the firm is in, and the number of its rivals.

\section{Slack Managerial Resources: A Model of the Trends}

This section tries to isolate some of the factors that may have given rise to secular changes in diversification. It looks at a closed, static economy with symmetric firms-equal in size and scope-and asks how exogenous increases in capital stock, population, Hicks-neutral technical change, management-biased technology, and aggregate level of product variety affect the level of diversification. The model addresses the time-series evidence only. The next section models differences in firms and addresses the cross-sectional evidence.

Suppose that consumers like variety and that the quantities of the various products enter into their utility functions symmetrically ${ }^{47}$ Let

44. Lichtenberg (1990).

45. For example, Jaffe (1986); and Scherer (1984). Many other empirical results are summarized by Griliches (1992).

46. Mansfield and others (1971, p. 221).

47. As, say, in the utility functions proposed by Spence (1976); and Dixit and Stiglitz (1977). 
$v$ be the total number of products in the economy. This number is exogenous. If these products enter utility functions and production functions in an exchangeable way, there will be an equilibrium in which they all sell at the same price, a price I normalize at 1 .

Each product is made with three factors of production: management $x$, capital $k$, and labor $l$. The quantity of the product, $q$, is given by $q$ $=f(x, k, l)$, where $f$ is increasing and strictly concave in $k$ and $l$.

The manager's input, $x$, is critical here. On the one hand, its fixed nature generates diversification of production, but on the other, its scarcity limits diversification. The manager's input may denote the intensity of managerial monitoring activities if there are agency problems, or the amount of information the manager can interpret, or simply the amount of time the manager devotes to overseeing the manufacture of the good in question. ${ }^{48}$ Moreover, one may prefer to think of $x$ much more generally as managerial talent, as any scarce specialized input, as organizational capital, or, indeed, as any other factor that is in fixed supply, at least in the short run.

An example will show how slack managerial resources can cause the firm to diversify. Suppose that the manager has one unit of time at his disposal, so that $x \leq 1$. The notion of "slack" in the firm's employment of the scarce specialized input can be captured by assuming that the returns to the managerial input diminish sharply beyond some point. Figure 1 plots two cases. For schedule A the marginal product of managerial time is 0 for $x \neq 1 / 2$. That is, it takes exactly half of the manager's time to run a product. As the figure shows, $f(x, k, l)=f(1 /$ $2, k, l)$ for all $x \geq 1 / 2$. If the firm were to make two products and devote $x=1 / 2$ to each product, its revenue would be $2 f(1 / 2, k, l)=$ $2 f(1, k, l)>f(1,2 k, 2 l)$, because $f$ is concave in $(k, l)$. Therefore, the firm would earn more revenue if it allocated its labor and capital equally to making two goods rather than one. And because its costs would be the same under the two scenarios, it would be better off making two goods. If the discontinuity in schedule A were at the onethird point rather than at the one-half point, the firm would make three products, not two, and so on. Of course, the world is not as dramatic

48. See Calvo and Wellisz (1978) for an analysis of monitoring activities, and Gifford (1992) for an analysis in a dynamic context. See Radner and Van Zandt (1992) for an analysis of information interpretation. 
Figure 1. Diversification Based on Slack Managerial Input

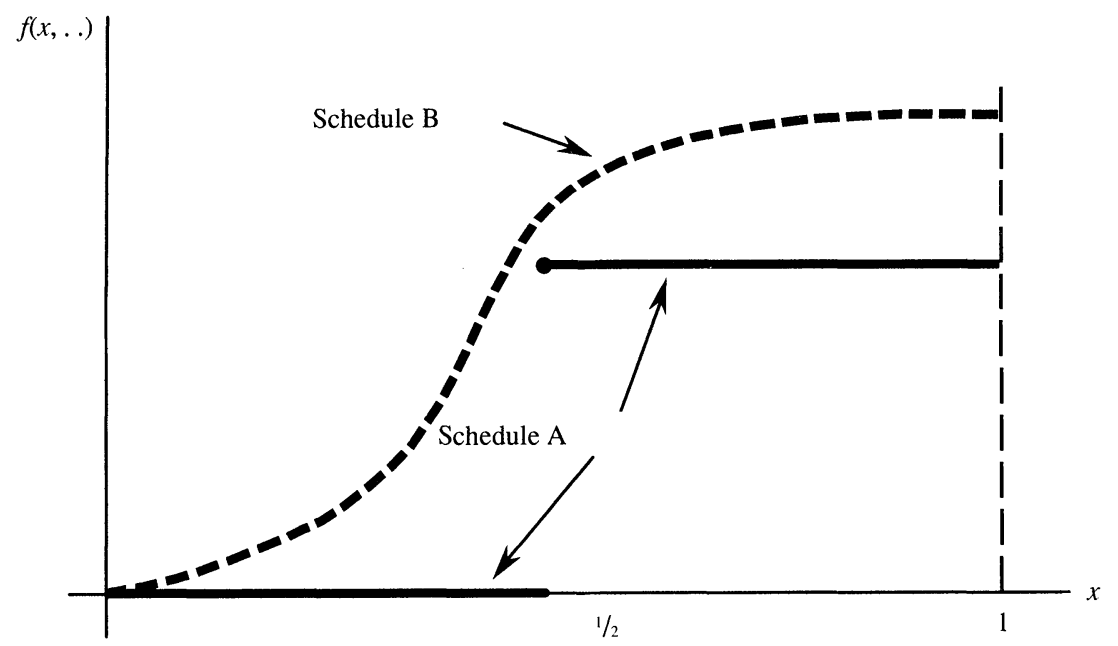

Source: See text for discussion of figure.

as schedule A depicts it to be. The model below assumes something similar to schedule B, which is less dramatic, but which has the same basic shape so that the firm has an incentive to diversify, but only to a limited extent.

The production function $f$ is the same for each good that the firm may want to produce, and it may choose to produce several. Let $n$ be the number of products that a firm makes. The firm produces the same amount of each good and uses the same quantity of inputs on the production of each.

The owner of the firm manages it himself. He cannot augment the managerial time input by hiring it from outside. ${ }^{49} \mathrm{He}$ has one unit of time at his disposal, and he spends it all on production: $x=1 / n$. Because the production function for each product is the same, and because all products sell at the same price, normalized at 1 , the firm's revenue is $n f(1 / n, k, l)$. Now let $F(\hat{k}, \hat{l})$ be the firm's revenue if it hires a total quantity of inputs $\hat{k}$ and $\hat{l}$ and uses them to produce the optimal number

49. One could let the owner hire managers and add layers of management as discussed by Beckmann (1977), but this would not alter my conclusions so long as the process involved some loss of control. 
of goods. Because its costs do not depend on $n$ once $\hat{k}$ and $\hat{l}$ are given, the firm will choose $n$ to maximize its revenue, and therefore

$$
F(\hat{k}, \hat{l})=\max _{n}\left\{n f\left(\frac{1}{n}, \frac{\hat{k}}{n}, \frac{\hat{l}}{n}\right)\right\} .
$$

Now imagine an economy with $L$ identical agents, each of whom has a unit of labor and an economy-wide capital stock $K$. This is Lucas's setup, but with identical agents and multiproduct firms.

Let $w$ be the wage and $r$ the rental on capital. (Any of the $v$ final goods can act as numeraire because each sells at the same price.) Each agent can either run his own firm, or work for someone else. In equilibrium, entrepreneurial income must equal the wage:

$$
\max _{\hat{k}, \hat{l}}\{F(\hat{k}, \hat{l})-r \hat{k}-w \hat{l}\}=w .
$$

Optimal employment of factors means that their marginal products must equal their prices: $F_{k}=r$, and $F_{l}=w$. Let $m$ be the number of managers so that the capital stock per manager is $K / m$, and the number of workers per manager is $(L-m) / m$. Thus, in equilibrium, equation 1 reads

$$
\begin{aligned}
F\left(\frac{K}{m}, \frac{L-m}{m}\right)-\frac{K}{m} F_{k}\left(\frac{K}{m}, \frac{L-m}{m}\right)^{\sim} \\
-\left(\frac{L-m}{m}\right) F_{l}\left(\frac{K}{m}, \frac{L-m}{m}\right)=F_{l}\left(\frac{K}{m}, \frac{L-m}{m}\right) .
\end{aligned}
$$

Rearrangement and cancellation lead to

$$
F\left(\frac{K}{m}, \frac{L}{m}-1\right)-\frac{K}{m} F_{k}\left(\frac{K}{m}, \frac{L}{m}-1\right)-\frac{L}{m} F_{l}\left(\frac{K}{m}, \frac{L}{m}-1\right)=0 .
$$

This equation yields the equilibrium number of managers $m$, conditional on the economy-wide endowment of capital and labor. Moreover, equilibrium maximizes the value of aggregate output, in the sense that $m$ solves the problem

$$
\max _{m}\left\{m F\left(\frac{K}{m}, \frac{L-m}{m}\right)\right\},
$$

subject to $0 \leq m \leq L$. This is the value of gross national product (GNP) 
when every good receives the same weight of unity. The output of all products combined is $m n q$, and since there are $v$ products in the economy, the aggregate output of each product is $m n q / v$.

I now turn to the time-series behavior of firm size as measured by employment per firm, $(L-m) / m$, and the time-series behavior of diversification. First, Hicks-neutral technical change leaves $m$ unchanged and therefore does not affect employment per firm.

Proposition 1 (Hicks-neutral technical change): Let $\lambda \mathrm{f}(\mathrm{x}, \mathrm{k}, \mathrm{l})$ be the production function for each product. Then neither $\mathrm{m}$ nor $\mathrm{n}$ depends on $\lambda$, whereas $\mathrm{r}$ and $\mathrm{w}$ are proportional to $\lambda$.

The assertion is true because in equation $1, F, r$, and $w$ are all scaled up by the same factor $\lambda$, so that the firm's factor demands are unchanged. And since equation 2 continues to hold, the value of $m$ is unchanged as well. Thus, Hicks-neutral technical change affects relative prices but not equilibrium activity.

This result should be interpreted with care; it holds in a static world and in a closed economy. In a dynamic world even Hicks-neutral technical change could affect accumulation of capital. And in an open economy, if other economies did not experience the same shift in production functions, there would be an inflow of resources ( $K$ is probably more mobile internationally than $L$ ), which could change factor proportions. Although some results that follow do deal with the case of changing factor proportions, the treatment of dynamic and possibly open economies diverges too far from the central theme of this paper to permit discussion here.

Second, the U.S. capital-labor ratio has increased in the past hundred years, and this is represented in the model by a secular rise in $K / L$. Both sales and employment per firm have increased over time, and the latter does not follow from Hicks-neutral technical change alone. Moreover, proportional increases in capital and labor do not affect factor employment per firm.

Proposition 2 (Proportional factor accumulation): Let $\lambda \mathrm{K}$ and $\lambda \mathrm{L}$ be the exogenous factor supplies. Then $\mathrm{n}, \mathrm{w}$, and $\mathrm{r}$ do not depend on $\lambda$, and $\mathrm{m}$ is proportional to $\lambda$. 
This assertion holds because unchanged $w$ and $r$ leave the firm's problem in equation 1 unchanged, and as a result, $n$ is also unchanged. Finally, because $m$ is proportional to $\lambda, K / m$ and $L / m$ do not depend on $\lambda$, and so equation 2 continues to hold.

In the United States, however, the capital stock has increased faster over the past century than the supply of labor. Between 1909 and 1957 the U.S. capital stock grew at 2.4 percent a year, while hours worked grew by only 1.3 percent, so that $K / L$ grew. ${ }^{50}$ If $L$ is seen as representing not the economy's stock of raw labor, but the number of efficiency units of labor, then I should adjust for the growth of education per labor force member, which Denison estimates grew by 0.9 percent during the same period. This means that the stock of efficiency units of labor grew by 2.2 percent-still less than the growth in $K .^{51}$ I will now show that employment per firm can rise in response to an increase in the economy-wide capital-labor ratio. This is a result that Lucas also proves in a different setting.

Proposition 3 (Increase in $\mathrm{K}$ ): If the elasticity of substitution between capital and labor is less than 1, an increase in the economy's stock of capital, K, will raise employment per firm by lowering $\mathrm{m}$.

To show the validity of this statement, I first differentiate equation 2 with respect to $K$ to obtain

$$
\frac{d m}{d K}=\frac{m\left(K F_{k k}+L F_{k l}\right)}{K^{2} F_{k k}+2 K L F_{k l}+L^{2} F_{l l}}<0 .
$$

The denominator is positive from the second-order conditions that guarantee an interior solution to the problem in equation 1. Lucas was dealing with a production function that was a concave transformation of a linearly homogeneous production function. Linear homogeneity of $F$ would imply that the numerator in equation 3 is 0 , and hence that $d m / d K=0,{ }^{52}$ but the concave transform renders the numerator, and hence $d m / d K$, negative. The intuition for the result is that when labor

50. Denison (1962).

51. Denison's (1985) estimates for the later period 1929-82 also show a rise in $K / L$, again even after allowing for the growth of labor skills.

52. If $F$ is linearly homogeneous, $F_{k}$ is homogeneous of degree 0 , and this implies the assertion. 
and capital are not too substitutable, the increase in the economy's capital stock raises wages more than it raises managerial returns and therefore causes an increase in the number of wage workers and an increase in firm size.

A corollary of propositions 2 and 3 is that an increase in labor supply, if unaccompanied by a corresponding increase in the capital stock, lowers employment per firm! Moreover, in the United States and elsewhere, per capita income has increased not only because $K / L$ has gone up, but also because of technical change, which Solow and many others have taken to be Hicks-neutral in nature. So to test the theory directly, one must relate employment per firm to measures of $K / L$, and not to income per capita, because the latter includes Hicks-neutral change in technology.

Figure 2 displays the behavior over time of the key variables. In the figure, $K$ is the gross private nonresidential capital stock, and $L$ is the labor force excluding government workers. These stand for the endowments of capital and labor. The variable $Y$ stands for GNP and $I$ is gross private domestic investment. To measure the number of firms, $m$, I use the longest available time series, which is the number of concerns. Since this measure excludes railways and the agricultural, finance, insurance, and real estate sectors, the number of concern workers, labeled $L^{*}$ in the figure, excludes workers in these sectors. ${ }^{53}$

Figure 2 shows that the capital-labor ratio does indeed track firm size fairly closely. The picture is different for the years of and around World War II, first because many small businesses shut down as their owner-operators joined the armed forces, and second because resources were shifted to the manufacture of ships, aircraft, tanks, weapons, and other items typically made by large firms. For both reasons, employment per firm went up dramatically. After the war ended, it took a couple of years for things to get back to normal.

By proposition 2, the ratio $L / m$ is homogeneous of degree 0 in $K$ and $L$, and so it must depend only on the ratio $K / L$. And by proposition 3 the ratio $L^{*} / m$ should be increasing in $K / L$. I test these propositions by regressing $L^{*} / m$ first on the $\log$ of the ratio $K / L$ and then on the logs

53. My variable $L^{*} / m$ is the same as the measure of concern size described in table 2 of Lucas (1978). The way in which these sources were updated and the exact calculation of each variable is described in the appendix. 


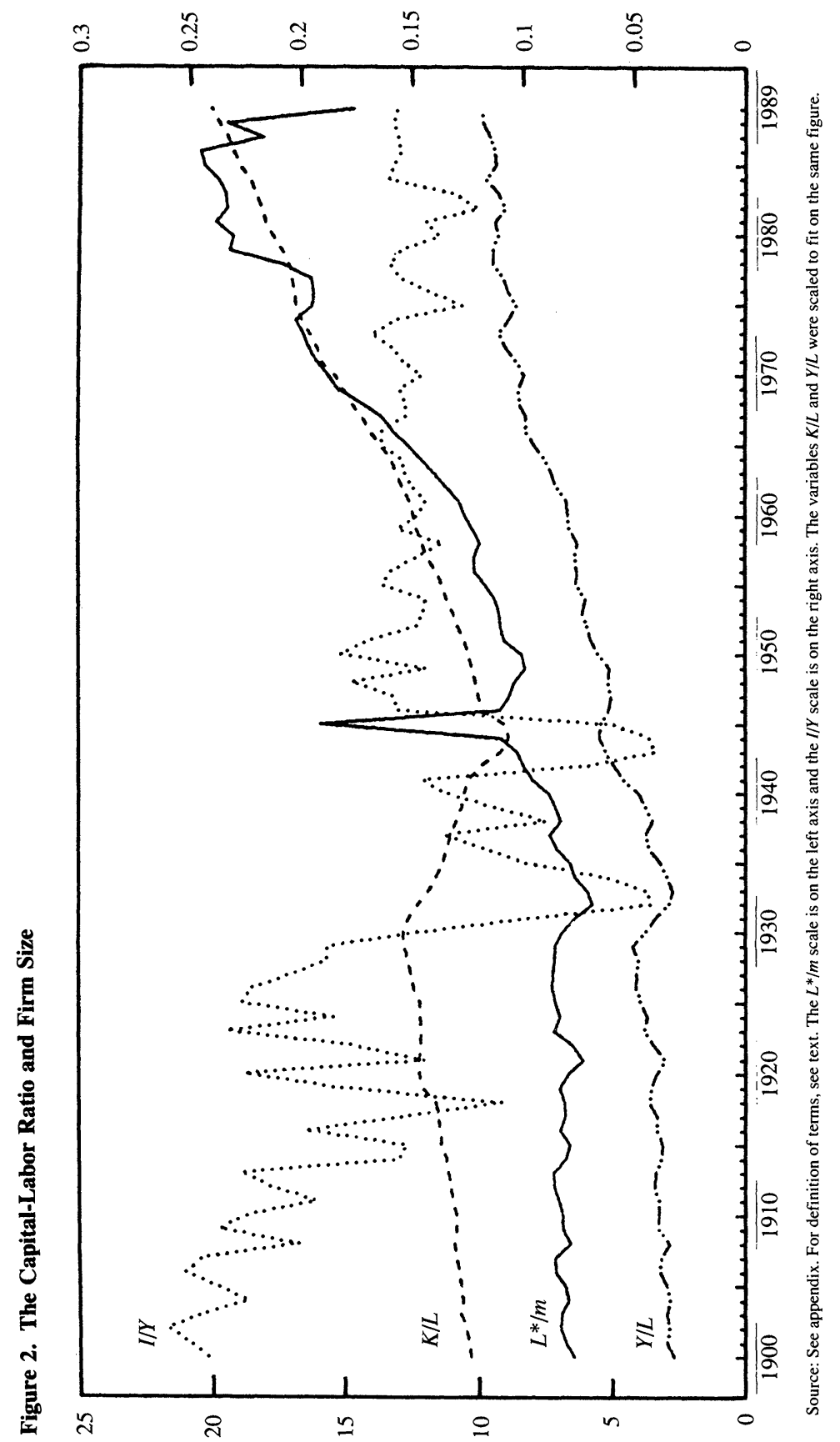


Table 1. Dependent Variable: Log of Employment per Concern $(L * / m)$

\begin{tabular}{lcccc}
\hline Variable & $(1)$ & $(2)$ & $(3)$ & $(4)$ \\
\hline Constant & 11.65 & -2.24 & 4.6 & 0.63 \\
& $(16.32)$ & $(1.79)$ & $(8.3)$ & $(0.63)$ \\
$\ln (K / L)$ & 2.11 & - & 0.82 & - \\
& $(13.14)$ & & $(7.38)$ & \\
$\ln K$ & - & 0.68 & - & 0.57 \\
& & $(4.40)$ & & $(5.26)$ \\
$\ln L$ & - & 0.00 & - & -0.27 \\
& & $(0.01)$ & & $(1.87)$ \\
$\ln (I / Y)$ & - & - & 0.34 & 0.24 \\
& & & $(16.28)$ & $(9.28)$ \\
$R^{2}$ & 0.689 & 0.889 & 0.930 & 0.948 \\
Number of observations & 80 & 80 & 80 & 80 \\
\hline
\end{tabular}

Source: Author's calculations and appendix. For definition of variables, see text. Numbers in parentheses are absolute value of $t$-statistics.

of $K$ and $L$ separately, and then by testing the restriction that their coefficients be equal and opposite in sign. The sample range was 190089 , but because of the extraordinary wartime patterns, the years 193948 were omitted. Using the remaining eighty annual observations, ordinary least squares produced the estimates summarized in table 1 .

Column (1) of table 1 shows that $K / L$ is positive and significant, as it should be. But column (2) shows that, contrary to the theory, $L$ fails to be significantly negative. An $f$-test rejects the restriction that the coefficients of $\log K$ and $\log L$ are equal and opposite in sign at the 99 percent significance level.

Most likely, $\ln L$ fails to come in with a significant negative coefficient in column (2) because of the cyclical correlation between the two variables induced by fixed costs of entry and exit associated with running a firm. Labor productivity, $Y / L$, and the labor force are both procyclical-they tend to move together with aggregate output. As figure 2 shows, firm size is also procyclical; most of the cyclical adjustment in output occurs through changes in firm size and not through changes in the number of firms, since fixed costs of entry and exit make it unprofitable to start and stop running a firm in response to transitory, cyclical events. Presumably, it is permanent changes in demand that bring about entry and exit in the market for a given product. Temporary changes (if correctly perceived as such) should be accommodated mainly 
by incumbents ${ }^{54}$ During boom periods the labor force usually expands (whereas in the model it is fixed at $L$ ), and because the fixed costs of starting a firm exceed the fixed costs of getting a job, most of the added labor market participants end up as workers, not as managers.

This cyclical correlation between the labor force and firm size clearly should not be taken as evidence against this static model, which is not meant to capture such cyclical patterns. Moreover, the procyclicality of mergers and takeovers is another reason why employment per firm is procyclical, and this too is an effect that this model of long-run behavior is not designed to explain. To deal with the cyclical issue, the next two regressions, described in columns (3) and (4) of table 1, include a cyclical variable - the logarithm of the investment-to-GNP ratio. This variable clearly captures the cyclical effect on $L / m$, and the coefficient of $\ln L$ now has the correct sign, although an $f$-test still rejects the "equal but opposite in sign" restriction at the 99 percent level.

Although the data formally reject the restrictions of the model, the model seems broadly consistent with the facts, and so one might ask if the increase in $K / L$ evident in figure 2 could also have caused diversification to go up. To keep things simple, I analyze this question under the added assumption that better management (in this case a larger $x$ ) lowers costs by the same percentage at all levels of output. ${ }^{55}$

\section{Separable Management Input}

Assume that the management input enters multiplicatively in the production function of each good: $f(x, k, l)=h(x) \phi(k, l)$. Let $\phi$ be increasing and strictly concave, and let $h$ be increasing, with $h(0)=$ 0 and convex near the origin; if it were concave, the owner would want to expand endlessly on the extensive margin as there would be asymptotically increasing returns to variety in production. ${ }^{56}$

As $x$ increases toward unity, $h$ must become convex; otherwise, the

54. Lucas (1978, p. 509) discusses this. Boeri and Cramer (1992) find support for this view in a sample of German firms.

55. Lucas $(1978$, p. 511) also assumes this.

56. This is because $h(1 / 2 n)>(1 / 2) h(0)+(1 / 2) h(1 / n)=(1 / 2) h(1 / n)$, hence $2 h(1 / 2 n)$ $>h(1 / n)$, and if the owner were making a profit on each of $n$ products, he could make a bigger one by making $2 n$ products using half the scale of inputs of $k$ and $l$ on each one. See the discussion of figure 1 . 
Figure 3. The Average Product of Managerial Time

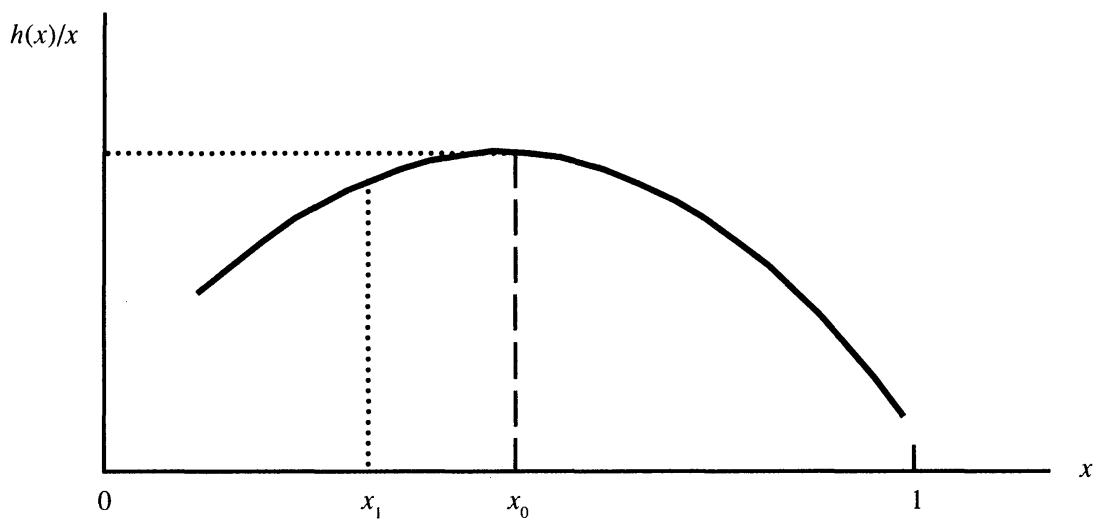

Source: See text for discussion of figure.

owner would want to run a single-product firm. Thus, I envisage $h(x)$ to be like schedule B in figure 1, in which case the average product of the owner's time looks as drawn in figure 3.

Setting aside the integer problem, it might look at first as if the manager would want to produce $1 / x_{0}$ goods, thereby maximizing the average product of his time. But this ignores the fact that he is earning positive profits on each brand and therefore has an incentive to produce more brands. Thus, the manager will choose a point like $x_{1}$, where $h^{\prime}$ is positive. And since $x_{1}$ is in the region between 0 and $x_{0}$ where $h$ is convex, this means that $h^{\prime \prime}\left(x_{1}\right)$ is positive.

To analyze this more formally, let $\pi(n)$ be the entrepreneur's net revenue per product:

$$
\pi(n)=\max _{k, l}\left\{h\left(\frac{1}{n}\right) \phi(k, l)-r k-w l\right\} .
$$

Indifference between management and wage work means that

$$
n \pi(n)=w .
$$

It is convenient to let $n$ take on all real values; an interior optimum for $n$ then satisfies $\pi(n)+n \pi^{\prime}(n)=0$, or, in view of equation 3 ,

$$
w=-n^{2} \pi^{\prime}(n) \text {. }
$$

But $\pi^{\prime}(n)=-h^{\prime}(1 / n) \phi / n^{2}$. Since $\pi^{\prime}$ is negative, this means that $h^{\prime}$ is 
Figure 4. The Determination of Managerial Input

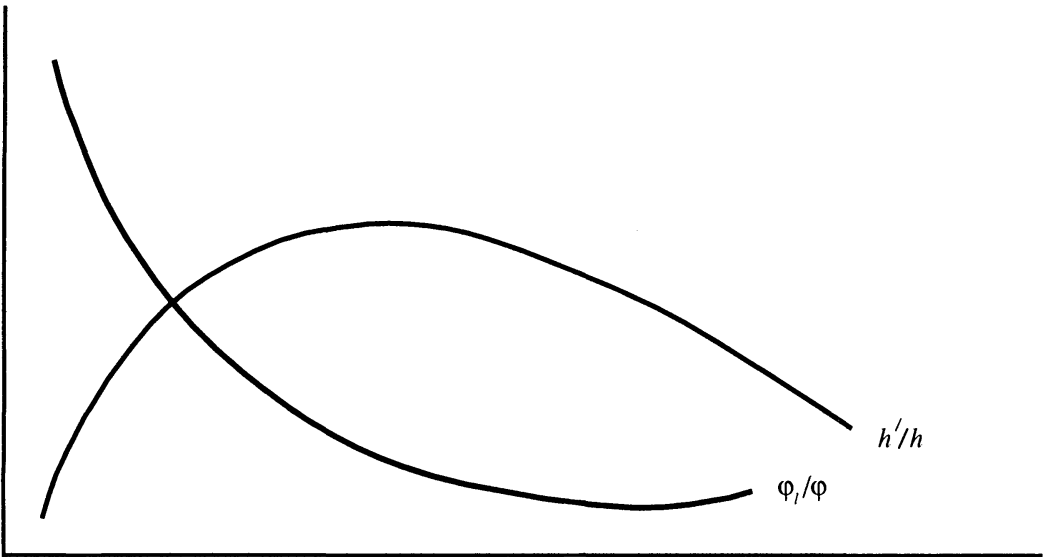

$x$

Source: See text for discussion of figure.

indeed positive at the optimum, as claimed in the discussion of figure 3. Optimal choice of labor input implies $w=h \phi_{l}$. Since equilibrium factor employment per product is $K / m n$ and $L / m n-1 / n$, equation 5 becomes

$$
\frac{h^{\prime}(x)}{h(x)}=\frac{\phi_{l}\left(\frac{x K}{m}, \frac{x L}{m}-x\right)}{\phi\left(\frac{x K}{m}, \frac{x L}{m}-x\right)},
$$

where $x=1 / n$.

Figure 4 shows the two sides of equation 6 plotted against $x$. In the region where $h$ is convex, $h^{\prime} / h$ increases, and thereafter it declines. From the discussion of figure 3 , it is clear that the curves must intersect on the rising portion of the $h^{\prime} / h$ curve.

Before plotting $\phi_{l} / \phi$, I specialize things a bit more. Assume with Lucas that $\phi(l, k)=\psi[\xi(l, k)]$, that $\xi$ is homogeneous of degree 1 , and that $\psi$ is an increasing concave function with $\psi(0)=0 .{ }^{57}$ Then

$$
\frac{\phi_{l}}{\phi}=\left(\frac{\psi^{\prime}}{\psi}\right) \xi_{l} .
$$

57. Lucas (1978, p. 511). 
Since $\xi$ is linearly homogeneous, $\xi_{l}$ is homogeneous of degree $0-$ it depends only on the capital-labor ratio. The capital-labor ratio is $K /$ $(L-\mathrm{m})$, and it does not depend on $x$. As $x$ rises, $x K / m$ and $x L / m-$ $x$ both increase (because $L / m>1$ ), which means that $\xi$ goes up and therefore that $\psi^{\prime}(\xi) / \psi(\xi)$ goes down. Therefore, $\phi_{l} / \phi$ declines with $x$, and the situation must be as depicted in figure 4 .

Now let me show that under some further conditions, diversification increases with an exogenous increase in $K$; that is, that $x$ declines when $K$ goes up. The increase in $K$ will lead to a resulting decrease in $m$ (see equation 3), but since $h^{\prime} / h$ depends neither on $K$ nor on $m$, it does not shift.

Now, there are two possibilities: the capital-labor ratio $k / l=k$ / $(L-m)$ will either rise or fall. First, take the case in which it falls. This happens if the negative response of $m$ to a rise in $K$ (given by equation 3 ) is sufficiently strong. In this case $\xi_{l}$ (being dependent only on the capital-labor ratio) falls because the capital-labor ratio has fallen. And the rise in both $x K / m$ and $(x L-x) / m$ for all $x$ means that $\xi$ is higher for all $x$. Therefore, $\phi_{l} / \phi$ shifts down for all $x$, and so diversification increases.

The second possibility is that $k / l$ goes up. This is the more likely case when the elasticity of substitution in $\xi$ is close to (but still less than) 1 , because then the induced change in $m$ is small. Since $\xi_{l l}<0$ and $d l / d K \geq 0$,

$$
\frac{d}{d K}\left(\frac{\psi_{l}}{\psi}\right)<\left[\left(\frac{\psi^{\prime}}{\psi}\right) \xi_{l k}+\xi_{l} \xi_{k} \frac{d}{d \xi} \frac{\psi^{\prime}(\xi)}{\psi(\xi)}\right] \frac{d k}{d K} .
$$

The right-hand side of this expression is negative if

$$
\frac{d \log \left(\psi^{\prime} / \psi\right)}{d \xi} \leq \frac{-\xi_{l k}}{\xi_{l} \xi_{k}},
$$

that is, if returns to scale (which depend inversely on the curvature of $\psi)$ diminish fast enough. For the CES production function $\xi(l, k)=$ $\left(\alpha k^{\rho}+(1-\alpha) l^{\rho}\right)^{\frac{1}{\rho}}$ (which, since $\sigma=1 /(1-\rho)$, must have $\rho<0$ for equation 3 to hold), the right-hand side of equation 8 reads $-1 / \sigma \xi$, so that 8 requires that

$$
\frac{d \log \left(\psi^{\prime} / \psi\right)}{d \log \xi} \leq-\frac{1}{\sigma}
$$


Equation 9 is sufficient, not necessary. Since the left-hand side is equal to $-R-\xi \psi^{\prime} / \psi$, where $R=-\xi \psi^{\prime \prime} / \psi^{\prime}$ is the Arrow-Pratt coefficient of relative risk aversion, ${ }^{58}$ equation 10 is equivalent to

$$
R \geq \frac{1}{\sigma}-\frac{\xi \psi^{\prime}}{\psi}
$$

Since $\psi^{\prime}>0$, equation 9 is met if $\psi$ has an Arrow-Pratt coefficient of relative risk aversion exceeding $1 / \sigma$, but this too is not a necessary condition. I have thus derived the following proposition:

PROPOSITION 4 (Diversification and the $\mathrm{K} / \mathrm{L}$ ratio): If $\mathrm{f}(\mathrm{x}, \mathrm{k}, 1)=$ $\mathrm{h}(\mathrm{x}) \psi[\xi(\mathrm{l}, \mathrm{k})]$ with $\psi$ strictly concave, and with $\xi$ being CES in form, and if $\psi$ has an Arrow-Pratt coefficient of relative risk aversion exceeding $1 / \sigma$, then an increase in $\mathrm{K} / \mathrm{L}$ increases firms' diversification.

This proposition says that the number of products made by a firm increases if the span of control falls off rapidly enough with the scale of each product. This ensures that the increased output per firm is transformed into more products, not just more output of each product.

Taken together, propositions 3 and 4 say that the trends toward bigness of firms and toward their greater diversification of production could have a common cause: the secular growth in the U.S. capitallabor ratio. If the elasticity of substitution is less than 1 , a relative reduction of managerial resources is induced, and both the number of workers and the number of products that each manager oversees increase.

\section{Management Innovations}

An innovation that helps a manager do a better job generally affects employment per firm and the level of diversification. The past century has seen innovations in bookkeeping methods, communication, transportation, and computation, all of which must have raised the effectiveness of managers. But the effect of these innovations on the size and scope of firms is ambiguous. To see why, let $\lambda_{1}$ be an index of managerial input-augmenting technology in scope, and $\lambda_{2}$ an index of

58. Pratt (1964). 
managerial-augmenting technology in scale. With my separability assumptions, this means that $f(x, k, l)=h\left(\lambda_{1} x\right) \psi\left[\lambda_{2} \xi(k, l)\right]$. Equations 6 and 7 then imply that

$$
\frac{\lambda_{1}}{\lambda_{2}} \frac{h^{\prime}\left(\lambda_{1} x\right)}{h\left(\lambda_{1} x\right)}=\xi_{l}(k, l) \frac{\psi^{\prime}\left[\lambda_{2} \xi(k, l)\right]}{\psi\left[\lambda_{2} \xi(k, l)\right]} .
$$

Depending on exactly how managerial innovation alters $\lambda_{1}$ and $\lambda_{2}$, any outcome is possible. Indeed, even if they change in the same proportion so that $\lambda_{1} / \lambda_{2}$ stays the same, more assumptions are needed on $h$ and $\psi$. This is because managerial innovation raises the output and the marginal product of capital and raw labor as well as that of management, and the effect on firms' scope and size is uncertain. So, although there is no doubt that innovations in communication and transportation have raised managers' productivity, one must assume more about what managers do before one can say much about this question. ${ }^{59}$

\section{Growth in Product Variety}

The past century has also seen a proliferation in the number of goods produced in the aggregate, and it seems natural that this trend should be related to the concurrent rise in diversification. In this model, however, there is no such relation. The parameter $v$ stands for the number of products in the economy, and yet it enters none of the equations. Exogenous changes in the economy-wide extent of product variety therefore have no effect on how diversified the average firm is. This implication may at first seem odd, but, as noted in the discussion preceeding proposition 1, the aggregate output of each product is $m n q / v$. Since $m, n$, and $q$ do not depend on $v$, it follows that the output of each variety is inversely proportional to the number of varieties, and that the value of GNP, $m n q$, also does not depend on $v$.

A change in $v$ may be thought of as a demand shift away from each good and toward all other goods. The resulting decrease in output of each variety is achieved entirely by a fall in the number of producers of each good, and not at all by a reduction in output per producer. That

59. The model also lacks any costs of using the market: the firm sells its output and hires factors at exogenous prices. Brynjolfsson and others (1991) argue that recent advances in information technology have made market-based coordination cheaper relative to internal coordination and have partially caused the recent decline in firm size and diversification. 
is, some of the good's suppliers exit, while those that remain do not change their output. In this respect, the model's implications coincide with those of Viner's U-shaped average cost model.

\section{Taxes}

Could some of the growth of employment per firm be attributable to changes in taxes? In other words, has the tax treatment of wage workers improved over time relative to that of firm owners? The answer is no. Before 1917 corporate income was taxed, but personal income was not. Since then personal income taxes have gone up faster than corporate taxes. As a result executive compensation has shifted away from salary and toward ownership income, and an increasing number of doctors, lawyers, and dentists have reduced their effective taxes by incorporating. By 1960 executives of large manufacturing companies earned nearly three times as much from dividends, capital gains, and stock compensation as they did from salaries. ${ }^{60}$ So firms have become less numerous relative to workers despite the relative improvement in corporate tax treatment.

What, then, are the factors that could have caused the secular increase in firms' diversification and employment? According to the model, the increase cannot be attributed to Hicks-neutral technical change, increases in population, the secular increase in product variety in the economy at large, or changes in taxes. Rather, it is the increase in the capital-labor ratio that is likely to have been a major cause. Changes in the technology of managing may have played a role.

Before moving on, the reader should note that the mathematics in this section can also be interpreted as describing a single good economy in which $n$ is the number of plants the firm uses to produce its product. If one added geographical space and transportation costs that increased with the distance between a supplier and its customers, one could use the model to analyze the geographical diversification of firms, which also has increased in recent times (witness the growth of multinational companies).

60. Lewellen (1971, pp. 152-4). King (1977, pp. 112-15) analyzes the incorporation decision when there are various forms of taxation. 
As it stands, the model cannot explain the cross-section phenomena described above, because in the model all firms are equally diversified. To address differences among firms, the next section adds heterogeneity in management skills to the model.

\section{R\&D Spillovers Among Products: A Model of the Cross-Sectional Evidence}

The strongest piece of cross-sectional evidence is the positive relation between R\&D intensity on the one hand and diversification on the other. This relation is stronger than the one between $R \& D$ intensity and firm size. The following model is designed to be consistent with both relations. To keep things simple, I shall now omit the capital input since it is inessential to what follows.

The production function for a good is $q=f(x, l, y, \theta)$. Once again, $x$ is the managerial input, $l$ is the input of labor into the production process, and $\theta$ is a characteristic that differs over managers. Output also depends on knowledge, $y$, specific to producing the good in question.

Production of knowledge $y$ uses only labor, called researchers. Researchers work on specific goods. Let $z$ be the number of researchers working on the product in question, and let $z^{\prime}$ be the number at work on each of the other products that the firm makes. Because a team of researchers may invent things that are useful to other teams of researchers, the knowledge $y$ relevant to making a product depends not only on the number of researchers $z$ working on that product, but also on the number $z^{\prime}$ working on each other product: $y=g\left(z, z^{\prime}, n ; \theta\right)$. To simplify, managerial time is now excluded from $g$, and instead, the firm owner's endowment of managerial talent, $\theta$, affects production. Note that $z^{\prime}$ pertains to the size of research teams on products made by the firm, not to the extent of research in other firms. Thus, there are no spillovers of knowledge among firms. Such spillovers would not change the model's positive implications. These require only that spillovers of knowledge among products within the firm exceed spillovers of knowledge among products across firms. This would preserve the incentive to diversify. If spillovers across firms were the same as spillovers within firms, no firm would diversify because it would be incur- 
ring organizational costs with no compensating benefit in the form of additional spillovers of knowledge. On the other hand, with spillovers of knowledge among firms, the competitive equilibrium would no longer maximize aggregate output.

The output of a firm's R\&D effort can be used only by the firm itself. There is no market for information. If there were, the spillover-capture motive for diversification would disappear. Rather than incur span-ofcontrol diseconomies, the firm could simply buy the necessary information. On these grounds, the motive to diversify for $R \& D$ reasons should be stronger in industries where innovations are not readily patented: in such industries, the sale of new knowledge may require a disclosure of information that would make it unnecessary for the wouldbe purchaser to pay for the new knowledge.

Since $g$ is the same for every product that the firm produces, the manager will make the research teams equal in size. As supplies of labor (research or other), people are perfect substitutes, so researchers and production workers sell their labor at the same price. Call this price the wage, $w$, denominated in units of output. The profit of a firm owned and run by a type $\theta$ individual is

$$
\pi(\theta, w)=\max _{n, l, z}\left\{n f\left[\frac{1}{n}, l, g(z, z, n ; \theta) ; \theta\right]-n w(l+z)\right\} .
$$

The price of each product is normalized at unity. The entrepreneur is a price taker-a negligible supplier in each product market that he chooses to enter. This assumption is important for the welfare implications of the model but not for most of its positive implications that I shall focus on here.

To deter the manager from trying to monopolize any product, assume decreasing returns to scale in the hired inputs $l$ and $z$. That is, for each $(n, \theta)$ pair, I ask that the function $f[1 / n, l, g(z, z, n ; \theta) ; \theta]$ be concave in $(l, z) .{ }^{61}$ Let $l(\theta, w)$ and $z(\theta, w)$ denote the optimal employment of

61. Arrow (1962), Radner (1970), and Wilson (1975) emphasize that a piece of information can be used on any scale. A more appropriate way to model the production process may then be $f(x, l, y ; \theta)=\phi(x, y ; \theta) l$, so that $x, y$, and $\theta$ all affect the productivity of the variable factor. This would be in the spirit of Beckmann's (1977) formulation. The problem is that if the constraint on $x$ and $n$ is $x=1 / n$, this setup has increasing returns to $l$ and $z$ (once one recognizes that $y$ is increasing in $z$ ). This could, however, be reconciled with competition if the constraint were changed to, say, $x=1 / \ln$, a constraint that makes 
workers and researchers per product, and let $n(\theta, w)$ be the choice of diversification, the number of products that the manager's firm makes.

The extent of product variety in the economy is exogenous. Spence and Dixit and Stiglitz have analyzed how the number of products in an economy gets determined as well as the relationship between the equilibrium number of products and their socially optimal number. ${ }^{62}$ Here the number of products is fixed, and anyone that wants to enter any product market can use, without cost, the technology described by $f$ and $g$. The fixity in the number of all products means, however, that the R\&D in this model yields process inventions rather than new products. More generally, this model cannot capture R\&D that aims to differentiate products.

People are all equally productive as workers and as researchers, but they differ in their managerial skills. Let $H(\theta)$ be the population distribution of the vector $\theta$. That is, $H(\theta)$ is the number of people with managerial talent not exceeding $\theta$. A person can either manage a firm or work for someone else. Let $A(w)$ be the set of people who prefer management to wage work. This set depends on the wage $w$ since the attractiveness of wage work relative to management increases with the wage. Then $A(w)=[\theta \mid \pi(\theta, w)>w]$ is the set of vectors $\theta$ that ensures that its owners will reap a higher payoff as managers than as workers. The number of firms will then equal the number of people whose characteristics are in this set.

If everyone chooses his or her preferred option, the supply of labor will be the number of people with $\theta$ s in the set $\sim A(w)$, which is the complement of the set $A(w)$. Labor demand will thus equal labor supply if

$$
\int_{A(w)} n(\theta, w)[l(\theta, w)+z(\theta, w)] d H(\theta)=\int_{\sim A(w)} d H(\theta) .
$$

The left-hand side is the demand for labor, and the right-hand side is its supply. The strict concavity of $f$ in $l$ and $z$ implies that labor demand

sense if management needs were to rise in proportion to total labor employed, as Beckmann assumes. Information-based theories of the Radner and Van Zandt (1992) type may shed light on the appropriate assumptions on $f$. I shall nevertheless proceed with the model as set out above.

62. Spence (1976); and Dixit and Stiglitz (1977). 
slopes down. Because $\pi$ is decreasing in $w$, the set $\sim A(w)$ grows as $w$ increases, and so labor supply slopes up. Therefore, a unique equilibrium wage exists.

Because knowledge is assumed not to spill over from firm to firm, one could also show that this equilibrium, like the one in the timeseries model, yields the maximal output, and hence is Pareto optimal. It is optimal under the constraint that people running firms cannot share their knowledge. This constraint is a natural one to impose given that the noncooperative situation does not offer entrepreneurs the chance to share information.

For more diversified firms to be bigger, it is enough that $n, x$, and $w$ all move in the same direction in response to changes in $\theta$. But this does not also guarantee that diversified firms are more R\&D intensive. One could derive general conditions on $f, g$, and $H$ sufficient for the second proposition to hold, but these conditions are complex, and they mean little unless $\theta$ itself stands for something specific. Therefore, I now specialize things a bit. First, consider again the case where the management input $x$ enters separably: $f(x, l, y, \theta)=h(x) l^{\beta} y^{\gamma}$, an oftenused formulation. ${ }^{63}$ The parameters of $h$, along with $\beta$ and $\gamma$, should be thought of as components of the vector $\theta$, and so should $\lambda$ and the parameters of $G$, defined below. Managers can differ in several dimensions. The function $h(x)$ has the same interpretation here as it did in the earlier model.

Second, let $y=g\left(z, z^{\prime}, n, \theta\right)=\lambda z+G(n) z^{\prime}$. The parameter $\lambda$ measures the response of product-specific knowledge to the employment of researchers working on the product itself; $G(n)$ measures the response of product-specific knowledge to employing researchers on each other product that the firm makes, and of course, there are $(n-1)$ other products. This assumption about $g$ resembles what Spence assumes about spillovers across firms that make the same product. ${ }^{64}$ At any rate, if $G(n)=0$, there are no spillovers and no incentive to diversify. My hypothesis is that diversification enables the capture of spillovers, so that $G(n)$ is an increasing function of $n$.

63. See Griliches (1979, p. 95).

64. Spence (1984) chooses units of $z$ so that $\lambda$ is unity. Then he focuses on the ratio $G(n) / \lambda$ as an index of knowledge spillover among firms. If $G(n)=\lambda$, the R\&D input is fully shareable. 
Substituting for $y$ into $f$ and noting that $x=1 / n$ implies that $q=$ $\Phi(n) l^{\beta} z^{\gamma}$, where $\phi(n)=h(1 / n)[\gamma+G(n)]^{\gamma}$. The manager maximizes the firm's profits: $\Phi(n) l^{\beta} z^{\gamma}-n w(l+z)$, where $\phi(n)=n \Phi(n)$. Assume that $\phi$ is increasing in $n$, at least for low values of $n$. The first-order condition for a maximum with respect to $n$ is $\phi^{\prime}(n) l^{\beta} z^{\gamma}-w(l+z)$ $=0$. The second-order condition for a maximum over $n$ is $\phi^{\prime \prime}<0$. Since $q=n^{-1} \phi(n) l^{\beta} z^{\gamma}$, the first order condition reads $n \frac{\phi^{\prime}(n)}{\phi(n)} q-w$ $(l+z)=0$. Now $w(l+z)$ is total labor cost, and in view of the CobbDouglas form, it equals $(\beta+\gamma) q$, because labor's share in output is $\beta+\gamma$. Thus, the first-order condition becomes

$$
\epsilon_{\phi n}=\beta+\gamma,
$$

where $\epsilon_{\phi n}=n \phi^{\prime} / \phi$ is the elasticity of $\phi$ with respect to $n$.

The effect on $n$ of variations in $\gamma$ is of special interest because $\gamma$ is the share of R\&D in output, a quantity that has been shown to be strongly related to diversification. To get cross-sectional variation in firms' R\&D intensities, it suffices to assume that $\gamma$ is a component of the vector $\theta$ of person-specific managerial attributes. Equation 11 implies the following:

PROPOSITION 5 (Diversification and $R \& D$ intensity): If $\epsilon_{\phi n}$ increases with $\mathrm{n}$, then both high $\beta$ and high $\gamma$ firms will be more diversified.

The elasticity $\epsilon_{\phi n}$ increases with $n$ if the marginal benefits to diversification do not fall off too rapidly. Explicitly,

$$
\epsilon_{\phi n}=1-\frac{h^{\prime}(1 / n)}{n h(1 / n)}+n G^{\prime}(n) \gamma[\lambda+G(n)]^{\gamma-2} .
$$

Now $-h^{\prime} / n h=-x h^{\prime}(x) / h(x)$, and this term decreases with $x$ if $h^{\prime \prime}>$ 0 . This inequality, as well as the inequality if $x h^{\prime}(x)<h$, follows from figure 4 and its discussion. Therefore, the term $-h^{\prime} / n h$ increases in $n$. The last term on the right-hand side of equation 12 can either increase or decrease in $n$, and it will decrease rapidly if $G^{\prime}$ decreases rapidly. On the other hand, if $G$ is convex, it can cause the second term to increase as well. It may at first appear that proposition 5 should follow more easily. The reason for the added conditions, however, is that a 
higher $\gamma$ also raises the manager's incentive to produce more of each product, that is, to raise scale rather than diversification.

Proposition 5 bears on the evidence showing a positive relation between R\&D and diversification. But what about the evidence showing that larger firms are more diversified? The model is consistent with this fact if the dominant source of variation in entrepreneurial ability is variation in how to use knowledge productively, that is, variation in the parameter $\gamma$. High $\gamma$ types run more R\&D-intensive firms. They also have larger sales. A corollary therefore is the following:

Proposition 6 (Diversification and sales): If $\gamma$ is the dominant source of variation in $\theta$ in the population of entrepreneurs, diversification will be positively related to sales.

If $\gamma$ is thought of as varying not among people but among sectors, then this proposition says that R\&D-intensive sectors should have larger firms in them than sectors that are not $R \& D$ intensive. This is certainly true because the R\&D-sales relation holds whether or not one controls for sector. The conditions of proposition 6 describe just one way in which bigger firms are more diversified; there are other, more natural ways. For example, some people may be better coordinators, and this would show up formally as variation among entrepreneurs in the form of the function $h$. Such variation could show up as variation in the parameter $\lambda_{1}$, introduced at the end of the previous section. To derive a version of proposition 6 involving $\lambda_{1}$, however, demands further assumptions. Instead of pursuing this line, I turn to making a rough estimate of the R\&D-based efficiencies associated with diversification. ${ }^{65}$

\section{Estimating the Relation Between Diversification and Spillovers}

Here I use an empirical result of Scherer's to show how one might begin to calculate efficiency gains attributable to the shared nature of

65. A further reason not to dwell on the diversification-size relation is that it would hold even in worlds very different from the one modeled here. Suppose, for example, that products were randomly assigned to firms - that some firms produced many products, some only a few. Unless the sales of each product were systematically related to the number of other products that their firm produced, the relation between firm size and diversification would be positive. 
the R\&D input. I interpret the exercise as yielding an estimate of the role of diversification in creating spillovers, although I shall later mention other interpretations too. Efficiency gains from greater R\&D spillovers depend on the response of $G(n)$ to increases in $n$. I interpret an estimate that Scherer got some time ago in the context of the model of this section. Then I mention some other interpretations and discuss problems of estimation.

Scherer's finding is best described in his own words:

Diversification appears to be unambiguously stimulative to patenting. The estimated coefficients suggest that a unit increase in the numbers equivalent diversification index, which would be a 16 percent increase over the mean level of diversification, is accompanied by a 3 to 9 percent increase in the average patent yield per million dollars of R\&D. ${ }^{66}$

Suppose that the number of patents the firm gets, $P$, is proportional to the firm's knowledge $y$ per product times the number of products $n$, and let the constant of proportionality be $\rho$. Then $P=\rho n y$. Evaluated at $z^{\prime}=z$, the equation $y=\lambda z+G(n) z^{\prime}$ implies that

$$
P=\rho[\lambda+G(n)] Z,
$$

where $Z(=n z)$ is the firm's total R\&D budget, which Scherer measures in millions of dollars. Thus, the average patent yield per million dollars of R\&D is $\rho[\lambda+G(n)]$. Now Scherer's measure of diversification is the inverse Herfindahl measure $1 / \sum_{j=1}^{n} S_{j}^{2}$, where $S_{j}$ is the share of the firm's sales stemming from the $j^{\text {th }}$ product. In the model $S_{j}=1 / n$, so that this measure equals exactly $n$. With this in mind, I can reinterpret Scherer's statement as saying that a 1 percent increase in $n$ is accompanied by a $3 / 16$ to $9 / 16$ percent increase in the patent yield. Since the patent yield is $\rho[\lambda+G(n)]$, this implies that

$$
\frac{3}{16} \leq \frac{n}{\rho[\lambda+G(n)]} \frac{\partial}{\partial n}\{\rho[\lambda+G(n)]\} \leq \frac{9}{16},
$$

or that

$$
\frac{3}{16} \leq \frac{n G^{\prime}(n)}{\lambda+G(n)} \leq \frac{9}{16} .
$$

66. Scherer (1983, p. 123). 
Now suppose that $R \& D$ done on another product is $\mu$ times as useful as the first product's own R\&D. Since there are $(n-1)$ other products, this implies that $G(n)=\mu \lambda(n-1)$. The size of $\mu$ would depend on the closeness of the firm's products in technology space. ${ }^{67} \mathrm{My}$ symmetric formulation insists, however, that $\mu$ be the same for all pairs of products. Since $G^{\prime}=\lambda \mu$, the parameter $\lambda$ cancels. Evaluating the ratio at the mean $n$ in Scherer's sample, which was 9.65 , yields the inequality $0.025 \leq \mu \leq 0.12$.

This pair of inequalities obtains if for $n \mathrm{I}$ use the mean number of products. In theory this number should also equal the mean value of Scherer's diversification statistic $1 / \sum_{j=1}^{n} S_{j}^{2}$. In fact, because $S_{j}$ is generally not equal to $1 / n$ for all $j$, this value has a median of 3 . Using this alternative value for $n$ yields the pair of inequalities $0.07 \leq \mu$ $\leq 0.30$.

The two pairs of inequalities differ because I have used a symmetric product model to fit a situation in which products yield the firm unequal revenues. The second interpretation for $n$ seems the more natural one, but if the two are weighed equally and the union of the sets is defined by the two pairs of inequalities, one gets $0.025 \leq \mu \leq 0.30$. Thus, the $R \& D$ of a two-product firm is $(1+\mu)$ times as productive as the $R \& D$ of a single-product firm, with $\mu$ ranging from 0.025 and 0.30 .

This is a rough estimate, and an imprecise one at that. Moreover, it is probably an overestimate for several reasons. First, $\mu$ is, in fact, likely to vary among firms and products, and in those products where it is high, firms will choose a higher value of $n$, precisely to capture the higher spillovers. This means that the equation has a random coefficient, $\mu$, and that the realized $\mu$ is possibly related to the value of both regressors, $Z$ and $n$. The result will be an upward bias on the estimate of the average $\mu$.

Second, firms do not diversify randomly but rather choose technologically related products - products that are close in technology space and that presumably have a higher value of $\mu$. So $\mu$ should be thought

67. Jaffe (1986) showed that the technological distance among firms, which he measured, mattered in determining the extent of technological spillovers among them. Spence (1984) used the same functional form to study spillovers across firms. He interpreted $\mu$ as the fraction of knowledge generated by firm $\mathrm{A}$ that leaks to firm $\mathrm{B}$. 
of as the spillover between a pair of products chosen at random from a firm's portfolio of products and not from the population of all products.

Third, there is the possibility of reverse causation from patenting to diversification. Because appropriability, ease, and effectiveness of patenting vary among sectors, ${ }^{68}$ and because diversification is partially driven by $R \& D$ spillovers, it pays to diversify into those activities where R\&D has a payoff in that its output can be protected by patents. Thus, the estimate that I have attributed to measuring the effect of diversification on productivity of $R \& D$ may in part reflect an effect that appropriability has on diversification.

Last, but foremost, my interpretation is that a given level of R\&D input, $Z$, produces $1+\mu$ as much knowledge in a two-product firm as it does in a one-product firm. Scherer, however, gives two distinct interpretations for his findings:

More diversified enterprises might have higher propensities to patent either because cross-fertilization among diverse industry technologies enhances the fecundity of $R \& D$ or because a diversified company is better able to commercialize offbeat inventions and hence is more likely to seek patent protection for them. ${ }^{69}$

His "fecundity" interpretation is the one that I have been using here. But the second says that it is not the total stock of knowledge that goes up with diversification, but rather the desire to patent the knowledge or the desire to protect the knowledge from being used by others. The second interpretation distinguishes knowledge from commercializable knowledge. The model would still make sense if $Y$ is redefined to stand for commercializable knowledge, but that would deny the reality that a firm can productively use a piece of knowledge that it nevertheless does not wish to patent. If, perhaps because of greater visibility, diversified firms were more likely to be targeted by imitators than singleproduct firms were, they might patent more. Or it may simply be that an inventor would not bother to patent an invention that could be used in only one line of business, but that he would patent it if it were usable in several businesses. To add propensity to patent to the model, one might write $P=\rho(n) n y$, where $\rho(n)$, the constant of proportionality,

68. For evidence on cross-industry variability in patent effectiveness, see Levin and others (1987, table 2).

69. Scherer (1983, p. 117). 
now increases with $n$. To distinguish the effect of $n$ on $\rho$ from its effect on $G$, one needs firms' $\mathrm{R} \& \mathrm{D}$ expenditures broken down by business application. The few studies that use detailed R\&D data, but not patent data, have found that synergies in R\&D are present, and this is independent evidence that $G^{\prime}$ is positive and increasing in $n .^{70}$

\section{Conclusions}

This paper has made two points. First, the historical increases in the diversification of production and in firm size can both be viewed as products of the same underlying force: the secular increase in the capitallabor ratio. Second, the positive cross-sectional association between firms' $R \& D$ intensity and diversification is probably the result of firms trying to internalize cross-product spillovers of productive knowledge, although my estimate of such spillovers is highly tentative.

Much remains to be done. First, both models treat products symmetrically, which is counterfactual in at least one important respect. Measures of diversification that emphasize the numerical diversity of firms' products show a secular increase. But Gort's data showed little change in the share of the firms' primary activities. According to Gort's data, these activities retained their importance relative to firms' secondary activities, and it was really firms' secondary activities that became more diversified over time. An empirical update is needed to see if this puzzling regularity has held up. If it has, it will need explaining.

Second, a dynamic analysis is needed. In my static model, the only way to interpret a merger is as a response to some external stimulus. And perhaps the big merger waves were indeed a mass response to such events. But mergers, takeovers, and dissolutions happen all the time, and surely not all of them are adjustments to macroeconomic events. When two firms decide to merge, they are probably responding to some change in their immediate environment. The change may be unforeseen, or it may be a natural step in the process of the growth and decline of firms. Thus, it may prove useful to embed the model of section 6 in a

70. The papers by Henderson and Cockburn (1993) and Helfat (1992) both look at the interaction of different types of R\&D done in the firm. Most of the evidence summarized here on the positive relation between diversification and $R \& D$ does not involve patent data. 
cost-reduction model ${ }^{71}$ or a model in which the firm's optimal product portfolio is unknown but is revealed through experience. ${ }^{72}$ More important, managerial resources are variable in the long run-albeit at a cost. ${ }^{73}$

Third, the role of management in raising the productivity of other factors should be more explicit than I have made it. The model has an arbitrary asymmetry: the managerial input affects the productivity of large firms differently from how it affects the productivity of diversified firms.

Finally, the link between horizontal integration of firms and the longrun growth of economies should be explored. If the engine of growth is fueled by spillovers of productive knowledge from one activity to the next, and if integrating activities under a firm's roof speeds up this transfer of knowledge, then the ease with which firms can integrate will affect the rate of growth of the economy. This would be true even if the rate of growth of product variety were exogenous. But the argument gains further weight if the speed at which product variety grows is in turn dependent on how easily firms can exploit the technological similarities among products. All of this suggests that antitrust action may have to trade off allocative efficiency gains today against lower output tomorrow.

\section{Appendix}

Following are the data sources and definitions of variables used for the plots in figure 2 and the regressions in table 1.

1. Gross national product in 1958 prices, denoted by $Y$ in figure 2 .

1900-70: Historical Statistics of the United States, F3.

1971-77: Statistical Abstract of the United States, 1978, table 710.

1978-84: Statistical Abstract of the United States, 1986, table 719.

1985-89: Statistical Abstract of the United States, 1991, table 698.

71. Such as the one in Flaherty (1980).

72. Resembling, perhaps, the model in Jovanovic (1982).

73. A possible starting point for modeling this is section 5 of Beckmann (1977), where he discusses the effect on profits from adding an extra layer of management. 
2. Labor force, denoted by $L$ in figure 2, after subtracting government workers.

1900-47: Historical Statistics of the United States, D1.

1948-70: Historical Statistics of the United States, D12.

1971-84: Statistical Abstract of the United States, 1986, table 658.

1985-89: Statistical Abstract of the United States, 1991, table 631.

Data for 1948-89 adjusted as described in Lucas (1978).

3. Number of concerns, denoted by $m$ in figure 2 .

1900-70: Historical Statistics of the United States, V20.

1970-84: Statistical Abstract of the United States, 1986, table 884.

1985-89: Statistical Abstract of the United States, 1991, table 881.

Data for 1985-89 are adjusted to be compatible with data for the previous years.

4. Number of concern employees, denoted by $L^{*}$ in figure 2 . It is calculated as $[a-b-c-d]$, where

$a=$ Total number of nonagricultural employees:

1900-70: Historical Statistics of the United States, D127.

1970-77: Statistical Abstract of the United States, 1978, table 654.

1978-84: Statistical Abstract of the United States, 1986, table 692.

1985-89: Statistical Abstract of the United States, 1991, table 631.

$b=$ Total number of finance, insurance, and real estate workers:

1900-70: Historical Statistics of the United States, D137.

1970-89: Same as in $a$.

$c=$ Total number of government workers:

1900-70: Historical Statistics of the United States, D139.

1970-89: Same as in $a$.

$d=$ Total number of railroad workers:

1900-46: Historical Statistics of the United States, D179.

1947-89: Employment, Hours and Earnings, United States, 1909 1990.

Annual data for 1900-46 are interpolated from decade data.

5. Capital: gross private nonresidential capital stock in 1958 prices, denoted by $K$ in figure 2 . 
1900-24: Kendrick (1961), pp. 320-22, table A-XV.

1925-89: Survey of Current Business, October 1990, various pages. Adjusted to 1958 prices.

Data for 1900-24 are adjusted to be compatible with data for the later years.

6. Investment: gross private domestic investment in 1958 prices, denoted by $I$ in figure 2 .

1900-28: Long Term Economic Growth, 1960-1970, pp. 186-87.

1929-82: National Income and Product Accounts of the United States, 1929-1989.

1983-89: Statistical Abstract of the United States, 1989, table 698. 


\section{Comments and Discussion}

Comment by Richard J. Gilbert: In his paper Boyan Jovanovic develops a general equilibrium theory of the degree of diversification by firms. This is a question that has intrigued economists at least since Coase's seminal paper on "The Nature of the Firm," and Jovanovic should be applauded for assaulting this important topic. There are few exercises that expose the frailties of microeconomic analysis more than lecturing to a group of MBAs about why Kodak should or should not have diversified into instant photography or why Raytheon should or should not have diversified into consumer electronics. For this reason alone, I welcome the attempt by Jovanovic to shed light on this subject. Yet it remains to be seen whether an industrial organization analysis based on neoclassical production theory can do the job or whether other approaches are necessary to understand the determinants of firms' decisions to diversify.

In Jovanovic's most basic model there are three inputs to production - managerial effort, capital, and nonmanagerial labor. Each product has an optimal scale of managerial effort beyond which additional effort yields diminishing returns. In his extreme example, firms are endowed with one unit of managerial effort, and the return to effort expended on any individual product is zero if the level of effort exceeds one-half. As a result, it is more efficient to make two products, each using one-half unit of managerial effort, $k$ units of capital, and $l$ units of labor, rather than to make one product at a larger scale using twice as much of each of the three inputs. That there are diminishing returns to product-specific management is, of course, a crucial assumption. In Jovanovic's setup, the firm economizes on resources by spreading managerial talent over several products, rather than focusing talent on one 
product and increasing its scale of production. Although this assumption is not implausible, it is not necessarily correct. Experience economies would favor concentrating production on one product to maximize movement down the learning curve. In a somewhat different context, the benefits of investment in quality improvements are likely to be proportional to total production. A larger scale of production could justify an increasing allocation of managerial effort, without reaching a point of diminishing returns.

The elegance of Jovanovic's model is in combining the elements of production analysis to describe the degree of specialization in a market equilibrium. He describes how increases in economy-wide labor and capital endowments may affect the size of firms and the degree of diversification (assuming that each firm has a fixed endowment of managerial resources), and he tests the results using economy-wide data. Jovanovic concludes that "the historical increases in the diversification of production and in firm size can both be viewed as products of the same underlying force: the secular growth in the U.S. capital-labor ratio." This is a provocative result, but it overlooks the heterogeneity of firms and industries and, instead, implicitly assumes that the change in the size and diversification of firms has been uniform over time and across industries. Jovanovic's review of the data offers little support for a stationary trend in the extent of diversification over time. Certainly, industries differ widely in the level of diversification, and the composition of U.S. industry has changed radically over the several decades that this empirical analysis considers. Furthermore, Jovanovic's theory of the span of managerial control does not fully account for the effects of mergers on measure of firm-level diversification. If a firm doubles in size by acquisition and in the process doubles the number of managers, R\&D personnel, and products, diversification increases at the firm level, but it is arguable whether any changes occur in managerial scope.

Jovanovic extends the model by introducing R\&D as another input to production, building on the strong empirical relation between R\&D intensity and the degree of diversification. In this extension, $R \& D$ is a shared input among all of a firm's products, and greater diversification allows the firm to capture more of the spillovers between products. An attractive feature of this formulation is that it allows for diversity in managerial ability, which is consistent with the large observed variance 
in the returns to firms in the same industry and in the diversification strategies that they employ. It does, however, raise many empirical questions. Not the least of which is causation between the level of R\&D, which generates new products, and the degree of diversification, which may increase the marginal productivity of R\&D.

The extended model begins to capture more of the idiosyncratic features of firm strategy and diversification, but it is still a model of the firm as a "black box." Firms differ in this model because they possess different endowments of managerial ability, and in equilibrium each firm chooses the strategy that is optimal given its endowments. One can question whether this approach can lead to a satisfactory description of diversification behavior. Firms that operate in similar industries have employed vastly different strategies, and markets appear to give managers considerable discretion to exercise their strategic choices. An example is the experience of GTE and NEC, as told by Prahalad and Hamel. ${ }^{1}$ Although the two companies once had a similar product mix, they pursued very different diversification paths. NEC was much more successful than GTE, but GTE survived nonetheless.

In the 1960s and 1970s, many companies pursued corporate strategies that emphasized diversification by acquisition. Most of these acquisitions generated disappointing returns. Although the parent firms paid a price in terms of diminished profitability, most of them still survived relatively intact. Diversification is now out of fashion in many industries. An example is the petroleum industry, in which many firms have become more specialized in particular segments of their core business, such as gasoline retailing or exploration, after a wave of relatively unsuccessful diversification. These corporate histories do not provide much support for a theory of diversification based on optimizing behavior. The market has allowed wide discretion for many corporate executives to follow different diversification strategies over time. Although some of these strategies have been costly, most of the firms and their managers who were responsible for these mistakes have survived, paying only a modest toll for their sins.

It remains to be seen whether the logic of firm diversification strategies can be addressed in a meaningful way using the type of model described in this paper. Management talent is complex and idiosyn-

1. Prahalad and Hamel (1990). 
cratic. It might be easier to leverage knowledge of optical lithography to the design of laser printers than to leverage knowledge of military radar systems to consumer electronics. These qualitative factors may go further in explaining the extent of firm diversification than a theory that relies on a functional form for the span of managerial control. In the field of competitive strategy, the emphasis has been on more qualitative characteristics of corporations, such as a firm's core competencies, its complementary assets, and its ability to make radical versus incremental innovations. Although these concepts are difficult to quantify and, perhaps for this reason, have been largely overlooked by traditional organization economists, they could be the key to a positive theory of (successful) diversification.

General Discussion: Dennis Mueller questioned the author's assertion that diversification through merger may be an attempt to capture R\&D efficiencies. He noted that merger premiums are extraordinarily high, many times the likely gain from R\&D spillovers. He suggested that those firms that diversify through mergers are likely to have large cash flows but to be in slow-growing industries characterized by low levels of R\&D intensity. Such firms, he asserted, are not attempting to merge for efficiency gains. Instead, he suggested that the link between firm size and executive compensation might be driving such mergers.

Mueller also questioned the author's link between diversification and R\&D intensity. He noted that Scherer's 1965 paper on this topic, which was cited, showed a link only for industries that were not R\&D intensive. If a firm in such an industry is diversified, according to Mueller, its diversification is likely to involve moving into an industry that is more R\&D-intensive, thus creating this link between diversification and $R \& D$ intensity. This kind of scenario is not connected to R\&D spillovers. Mueller did admit, however, that Grabowski's work on two R\&D-intensive industries - pharmaceuticals and chemicals - had suggested that there might be a link between R\&D spillovers and diversification.

Zvi Griliches argued that different measures of diversification yield different results about diversification trends over time and about the potential for R\&D spillovers from this process. Diversification, he said, could be product diversification within a firm, product diversification within a factory, or diversification in terms of factories per firm. Whether 
there were likely to be increasing returns to scale-from managerial control or R\&D spillovers - depended upon what type of diversification was being focused upon. He noted that the Bureau of Labor Statistics might regard two bottles of the same kind of pills-one with 50 pills and one with 100 - as two different commodities. One would not expect R\&D economies of scale from this type of "diversification," Griliches said.

Ariel Pakes said that the author's model seemed to be particularly relevant to the consumer electronics industry, which he was working on. Pakes argued that within that industry, technology tended to be applicable to more than one product and noted that when a consumer electronic firm's share increased in one part of the market, it seemed to increase in other parts as well.

Peter Pashigian recalled the idea of treating large firms as a collection of small firms. When one looked at the distribution of growth or profit rates of these "small firms" and extrapolated them to what the distribution of growth or profit rates would be for the large firms, they should fall by 1 over the square root of $n$, yet the evidence shows that this is not the case. So, according to Pashigian, there must be some kind of correlation among units. He suggested that this be used as a measure of diversification, which should come through R\&D spillovers or less loss of managerial control.

Robert Willig raised the issue of geographical diversification, noting that from an industrial organization perspective, different parts of the world might be viewed as different markets. He said that just as different plants need different managers, so too do different regions need different managers. Willig argued that the idea of trading off between span of control and the principal-agent problems involved in larger firms would apply both to product line and geographical diversities. He wondered whether any measures of diversification take into account both product-line and geographical diversification and if the empirical regularities would hold up under such an expanded perspective.

Robert McGuckin noted that Mary Streitweiser at the Census Bureau had done work on individual plants in sixteen industries. Although these plants all had the same primary activity, they had very different sets of secondary activities, that is, their diversification was very different. Her work, according to McGuckin, suggested that there were some firm-level spillovers in the choice of products made at commonly owned 
plants. McGuckin also argued that managerial slack, sometimes referred to as organizational capital, was not just a factor that had a fixed relationship to span of control. It was not a fixed factor, but rather varied as the potential for productivity gains increased.

Linda Cohen noted that the author had modeled R\&D spillovers as a linear function. She said that if, instead, there are increasing returns to scale, one should not evaluate diversification at the median position but should look at the most diversified industries. 


\section{References}

Amihud, Yakov, and Baruch Lev. 1981. "Risk Reduction as a Managerial Motive for Conglomerate Mergers." Bell Journal of Economics 12 (Autumn): 605-17.

Arrow, Kenneth. 1962. "The Allocation of Resources for Invention.” In Richard Nelson, ed., The Rate and Direction of Inventive Activity: Economic and Social Factors. Princeton, N.J.: Princeton University Press.

Baldwin, John R., and Paul K. Gorecki. 1987. "Plant Creation versus Plant Acquisition: The Entry Process in Canadian Manufacturing." International Journal of Industrial Organization 5 (March): 27-42.

Baumol, William, John Panzar, and Robert Willig. 1982. Contestable Markets and the Theory of Industry Structure. New York: Harcourt Brace Jovanovich.

Beckmann, Martin J. 1977. "Management Production Functions and the Theory of the Firm," Journal of Economic Theory 14 (February): 1-18.

Berle, Adolf A., and Gardner C. Means. 1968. The Modern Corporation and Private Property. 2d ed. New York: Macmillan.

Berry, Charles H. 1975. Corporate Growth and Diversification. Princeton, N.J.: Princeton University Press.

Boeri, Tito, and Ulrich Cramer. 1992. "Employment Growth, Incumbents, and Entrants: Evidence from Germany.' International Journal of Industrial Organization 10 (December): 545-65.

Brynjolfsson, Erik, and others. 1991. "Does Information Technology Lead to Smaller Firms?' Center for Coordination Science, MIT, September.

Calvo, Guillermo A., and Stanislaw Wellisz. 1978. "Supervision Loss of Control and the Optimum Size of Firm." Journal of Political Economy 86 (October): 943-52.

Chandler, Alfred D., Jr. 1977. The Visible Hand: The Managerial Revolution in American Business. Cambridge, Mass: Belknap Press.

Chang, Sea Jin. 1992. " A Knowledge-Based Perspective on Corporate Growth: Entry, Exit, and Economic Performance During 1981-1989.' Ph.D. diss., Wharton School, University of Pennsylvania.

Denison, Edward F. 1962. The Sources of Economic Growth in the United States. New York: Committee for Economic Develoment.

- 1985. Trends in American Economic Growth, 1929-1982. Brookings.

Dixit, Avinash K., and Joseph E. Stiglitz. 1977. "Monopolistic Competition and Optimum Product Diversity." American Economic Review 67 (June): 297-308.

Elixmann, Dieter H. 1989. "Econometric Estimation of Economies of Scale and Scope in the German Telecommunications Sector." Wissenschaftliches Institut fur Kommunikationsdienste der Deutschen Bundespost, April. 
Evans, David S., and James J. Heckman. 1984. “A Test for Subadditivity of the Cost Function with an Application to the Bell System.' American Economic Review 74 (September): 615-23.

Fazzari, Steven M., Glenn Hubbard, and Bruce C. Petersen. 1988. "Financing Constraints and Corporate Investment." Brookings Papers on Economic Activity 1:141-95.

Flaherty, Therese M. 1980. “Industry Structure and Cost-Reducing Investment.', Econometrica 48 (July): 1187-1209.

Gertler, Mark, and Simon Gilchrist. 1992. ' Monetary Policy, Business Cycles, and the Behavior of Small Manufacturing Firms.'” New York University and Federal Reserve Board. November.

Gifford, Sharon. 1992. "Innovation, Firm Size, and Growth in a Centralized Organization.' Rand Journal of Economics 23 (Summer): 284-98.

Gollop, Frank, and James Monahan. 1991. "A Generalized Index of Diversification: Trends in U.S. Manufacturing.' Review of Economics and Statistics 73 (May): 318-30.

Gort, Michael. 1962. Diversification and Integration in American Industry. Princeton, N.J.: Princeton University Press.

1966. “'Diversification, Mergers, and Profits.' In William W. Alberts and Joel E. Segall, eds., The Corporate Merger. Chicago: University of Chicago Press.

. 1969. “'An Economic Disturbance Theory of Mergers, Quarterly Journal of Economics 83 (November): 624-42.

Goto, Akira. 1981. "Statistical Evidence on the Diversification of Japanese Large Firms.' Journal of Industrial Economics 29 (3): 271-78.

Grabowski, Henry G. 1968. "'The Determinants of Industrial Research and Development: A Study of the Chemical, Drug, and Petroleum Industries.', Journal of Political Economy 76 (March-April): 292-306.

Griliches, Zvi. 1979. "Issues in Assessing the Contribution of Research and Development to Productivity Growth.' Bell Journal of Economics 10 (Spring): 92-116.

1992. "The Search for R\&D Spillovers."' Scandanavian Journal of Economics 94 (Supplement): 29-47.

Hall, Bronwyn. 1988. "The Effect of Takeover Activity on Corporate Research and Development." In Alan Auerbach, ed., Corporate Takeovers: Causes and Consequences. Chicago: University of Chicago Press.

. 1990. "The Impact of Corporate Restructuring on Industrial R\&D.", Brookings Papers on Economic Activity: Microeconomics, 1990: 85-124.

Helfat, Constance E. 1992. "Know-how Complementaries and Knowledge Transfer within Firms: The Case of R\&D.' Wharton School, University of Pennsylvania, November.

Henderson, Rebecca, and Iain Cockburn. 1993. "'Scale, Scope, and Spillovers: 
Research Strategy and Research Productivity in the Pharmaceutical Industry." University of British Columbia, January.

Hill, Charles, and Gary Hansen. 1991. "A Longitudinal Study of the Cause and Consequence of Changes in Diversification in the U.S. Pharmaceutical Industry, 1977-86."' Strategic Management Journal 12 (March): 187-99.

Himmelberg, Charles P., and Bruce C. Petersen. 1991. "R\&D and Internal Finance: A Panel Study of Firms in High-Tech Industries.' Stern School, New York University, June.

Hughes, Kristy. 1988. "Concentration and Diversification of R\&D in a Conglomerate World.' 'Oxford Bulletin of Economics and Statistics 50 (August): 243-61.

Hunter, William C., and Stephen G. Timme. 1986. “Technical Change, Organizational Form, and the Structure of Bank Production." Journal of Money, Credit, and Banking 18 (May): 152-66.

Jacquemin, Alexis P., and Charles H. Berry. 1979. "Entropy Measure of Diversification and Corporate Growth."' Journal of Industrial Economics 27 (June): 359-69.

Jaffe, Adam B. 1986. "Technological Opportunity and Spillovers of R\&D: Evidence from Firms' Patents, Profits, and Market Value.' American Economic Review 76 (December):984-1001.

Jovanovic, Boyan. 1982. "Selection and the Evolution of Industry." Econometrica 57 (May): 649-70.

Kendrick, John W. 1961. Productivity Trends in the United States. Princeton, N.J.: Princeton University Press.

Kihlstrom, Richard E., and Jean-Jacques Laffont. 1979. "A General Equilibrium Entrepreneurial Theory of Firm Formation Based on Risk Aversion." Journal of Political Economy 87 (August): 719-48.

Kim, Youn H. 1986. "Economies of Scale and Economies of Scope in Multiproduct Financial Institutions: Further Evidence from Credit Unions.' Journal of Money, Credit, and Banking 18 (May): 220-6.

. 1987. "Economies of Scale in Multi-product Firms: An Empirical Analysis."' Economica 54 (May): 185-206.

King, Mervyn A. 1977. Public Policy and the Corporation. London: Chapman and Hall.

Kiss, Ferenc, and Bernard Lefebvre. 1987. "Econometric Models of Telecommunications Firms." Revue Economique 38 (March): 307-74.

Klavans, Richard. 1989. "Business Relatedness, and Business Performance." Line of Business Research Paper 83, Federal Trade Commission, Washington, D.C.

Levin, Richard, and others. 1987. "Appropriating the Returns from Industrial Research and Development.' Brookings Papers on Economic Activity: Microeconomics, 1987: 783-820. 
Levy, Haim, and Marshall Sarnat. 1970. "Diversification, Portfolio Analysis, and the Uneasy Case for Conglomerate Mergers.' Journal of Finance 25 (September): 795-802.

Lewellen, Wilbur. 1971. The Ownership Income of Management. New York: Columbia University Press.

Lichtenberg, Frank R. 1990. “Industrial Diversification and Its Consequences for Productivity.' NBER Working Paper 3231. Cambridge, Mass.: National Bureau of Economic Research. January.

- 1991. "The Managerial Response to Regulation of Financial Reporting for Segments of a Business Enterprise." Journal of Regulatory Economics 3: $241-49$.

Lucas, Robert E., Jr. 1978. "On the Size Distribution of Business Firms." Bell Journal of Economics 9 (Autumn): 508-23.

- forthcoming. "Making a Miracle." Econometrica.

MacDonald, James M. 1985. "R\&D and the Direction of Diversification." Review of Economics and Statistics 67 (November): 583-90.

McCutcheon, Barbara. 1990. "Investment and Financing Constraints: An Empirical Investigation of Internal Capital Markets in Conglomerates." Working Paper 91-01. University of Iowa. January.

Mansfield, Edwin, and others. 1971. Research and Innovation in the Modern Corporation. New York: Norton.

Matthews, John. 1981. "Multiproduct Economies of Scale in the Securities Industry.' U.S. Securities and Exchange Commission Capital Market Working Paper 7. Washington, D.C. March.

Morck, Randall, Andrei Shleifer, and Robert W. Vishny. 1990. "Do Managerial Objectives Drive Bad Acquisitions?" Journal of Finance 45 (March): 31-48.

Mueller, Dennis. 1969. “A Theory of Conglomerate Mergers." Quarterly Journal of Economics 83 (November): 643-59.

Nelson, Ralph L. 1959. Merger Movements in American Industry, 1895-1956. Princeton, N.J.: Princeton University Press.

Nelson, Richard R. 1959. "The Simple Economics of Basic Scientific Research.' Journal of Political Economy 67 (June): 297-306.

Panzar, John C., and Robert D. Willig. 1981. “Economies of Scope." American Economic Review 71 (May): 268-72.

Penrose, Edith. 1959. The Growth of the Firm. White Plains, N.Y.: Sharpe.

Prahalad, C. K., and Gary Hamel. 1990. “The Core Competence of the Corporation." Harvard Business Review 90 (May-June): 79-91.

Prais, S. J. 1976. The Evolution of Giant Firms in Britain: A Study of the Growth of Concentration in Manufacturing Industry in Britain, 1909-70. New York: Cambridge University Press. 
Pratt, John W. 1964. "Risk Aversion in the Small and in the Large." Econometrica 32 (January-April): 122-36.

Prescott, Edward, and Michael Visscher. 1980. "Organization Capital." Journal of Political Economy 88 (June): 446-61.

Radner, Roy. 1970. "Problems in the Theory of Markets under Uncertainty." American Economic Review 60 (May): 454-60.

Radner, Roy, and Tim Van Zandt. 1992. "Information Processing in Firms and Returns to Scale." Annales d'Economie et de Statisique 25/26:265-98.

Ravenscraft, David J., and Frederic M. Scherer. 1987. Mergers, Sell-Offs, and Economic Efficiency. Brookings.

Scherer, Frederic M. 1965. "Firm Size, Market Structure, Opportunity, and the Output of Patented Inventions." American Economic Review 55:10971125 .

\section{ed., Boston: Houghton Mifflin.}

- 1983. "The Propensity to Patent."' International Journal of Industrial Organization 1 (March): 107-28.

. 1984. "Using Linked Patent and R\&D Data to Measure Interindustry Technology Flows.' In Zvi Griliches, ed., R\&D, Patents, and Productivity. Chicago: University of Chicago Press.

Scherer, Frederic M., and others. 1975. The Economics of Multiplant Operation. Cambridge, Mass.: Harvard University Press.

Silk, Alvin J., and Ernst R. Berndt. 1990. "Scale and Scope Effects on Advertising Agency Costs." NBER Working Paper 3463. Cambridge, Mass.: National Bureau of Economic Research. October.

Spence, Michael A. 1976. "Product Selection, Fixed Costs, and Monopolistic Competition." Review of Economic Studies 43 (June): 217-35.

- 1984. "Cost Reduction, Competition, and Industry Performance." Econometrica 52 (January): 101-21.

Stigler, George. 1962. "Foreword." In Michael Gort, Diversification and Integration in American Industry. Princeton, N.J.: Princeton University Press.

Stokey, Nancy. 1988. "Learning by Doing and the Introduction of New Goods." Journal of Political Economy 96 (August): 701-17.

Streitweiser, Mary. 1991. "The Extent and Nature of Establishment-Level Diversification in Sixteen U.S. Industries.' Journal of Law and Economics 34 (October, pt. 2): 503-34.

Strickland, Allyn D. 1984. Firm Diversification, Mutual Forebearance Behavior, and Price-Cost Margins. New York: Garland Publishing.

Teece, David. 1980. "Economies of Scope and the Scope of the Enterprise." Journal of Economic Behavior and Organization 1 (September): 223-47.

United States Department of Labor, Bureau of Labor Statistics. 1991. Em- 
ployment, Hours, and Earnings, United States, 1909-90. Washington, D.C.: Government Printing Office.

United States Bureau of the Census. various years. Statistical Abstract of the United States. Washington, D.C.: Government Printing Office.

United States Department of Commerce. 1973. Long Term Economic Growth 1860-1970. Washington, D.C.: Government Printing Office.

-1975. Historical Statistics of the United States: Colonial Times to 1970. Washington, D.C.: Government Printing Office.

- 1990. Survey of Current Business. Washington, D.C.: Government Printing Office. October.

United States Department of Justice and the Federal Trade Commission. 1992. Horizontal Merger Guidelines. Washington, D.C.: Government Printing Office. April.

Utton, Michael A. 1981. Diversification and Competition. New York: Cambridge University Press.

Wall Street Journal. 1992. "For New Jobs, Help Small Business.” August 10.

Williamson, Oliver. 1979. "Transactions-Cost Economies: The Governance of Contractual Relations." Journal of Law and Economics 22 (October): 233-62.

Willig, Robert. 1991. “Merger Analysis, Industrial Organization Theory, and Merger Guidelines." Brookings Papers on Economic Activity: Microeconomics, 1991: 281-332.

Wilson, Robert. 1975. "Informational Economies of Scale." Bell Journal of Economics 6 (Spring): 184-95.

Young, Alwyn. 1991. "Learning by Doing and the Dynamic Effects of International Trade."' Quarterly Journal of Economics 106 (May): 369-406. 